\author{
KRZYSZTOF NARECKI \\ Katolicki Uniwersytet Lubelski Jana Pawła II \\ ORCID: 0000-0003-0384-3698 \\ e-mail: krzysztof.narecki@kul.pl
}

\title{
EUTHYMIA WE FRAGMENTACH DEMOKRYTA Z ABDERY
}

\begin{abstract}
Krzysztof Narecki, „Euthymia” we fragmentach Demokryta z Abdery (Euthymia in the fragments of Democritus of Abdera).

The author carries out a thorough philological analysis of 9 fragments of Democritus, in which both the noun $\varepsilon \cup \dot{\theta} v \mu$ í and related verbs and adjectives appear. This allows to establish the contextual semantic scope of the basic concept and to define the role it plays in Democritus' ethical thought.
\end{abstract}

Keywords: euthymia (euthymiē); euestō; eudaimonia; Democritus; cheerfulness; contentment; wellspiritedness; good disposition; well-being; Democritean ethics

Myśl Demokryta, twórcy - wraz z Leukipposem - koncepcji atomizmu, nauki rozwiniętej już w postać systemu uwzględniającego także etykę, stała się w ostatnich dziesięcioleciach często podejmowanym - na tle innych przedsokratyków - przedmiotem studiów badaczy, szczególnie chętnie zajmujących się tematyką moralną Abderyty. Trudno się temu dziwić, skoro żył on i działał w epoce Sokratesa, który w Platońskim Gorgiaszu zadaje swojemu rozmówcy, Kalliklesowi, i - jak można przypuszczać - także sobie współczesnym fundamentalne pytanie: „Jak należy żyć”1. W domniemanej odpowiedzi Demokryt,

${ }^{1}$ Odnosząc się w tym miejscu do opinii Recenzenta/-tki, wyrażam wdzięczność za wyrażone w niej sugestie, które biorę sobie do serca i w kolejnych pracach z pewnością uwzględnię. Aby jednak moje założenia (w tym właśnie studium) były w pełni przejrzyste i zrozumiałe, wyjaśniam, iż 1. Niektóre greckie fragmenty Demokryta, w których nie pojawia się tytułowe pojęcie (i jemu pokrewne), zamieszczam jedynie w przypisach, traktując je jako szeroki kontekst służący analizie tegoż pojęcia; 2 . W tekście głównym zamieszczam zarówno oryginalne fragmenty, jak i ich autorskie thumaczenia; 3. Przywołuję i podejmuję dyskusję naukową (tam, gdzie uznaję to za stosowne) jedynie w przypisach. Wszystkie te metodologiczne zabiegi czynię świadomie - podporządkowując narrację naczelnemu zamiarowi (jakim jest zbadanie kontekstualnego znaczenia pojęcia euthymia, a także określenie funkcji, jaką pełni ono w myśli etycznej Abderyty) - w przekonaniu, że mają one służyć nie tylko przejrzystości tekstu i przekazu, ale także Odbiorcy/Czytelnikowi, którym niekoniecznie będzie filolog ze znajomością starożytnej greki.

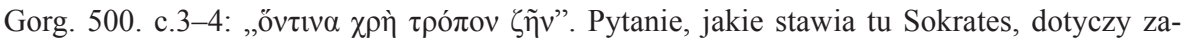
sadniczej według niego różnicy między życiem mówców uprawiających retorykę a życiem tych, 
jako pierwszy w historii greckiej filozofii, sugeruje, że celem życia człowieka jest stan szczęścia ${ }^{2}$, ale tylko wówczas, gdy polega on nie na przyjemnościach ciała, lecz duszy. Co więcej, gwarancją osiągnięcia takiego stanu, za czym

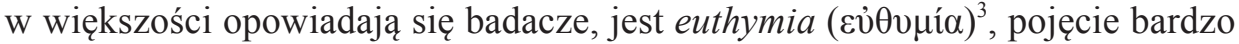
istotne, o ile nie podstawowe w etyce Demokryta ${ }^{4}$, sprawiające jednak sporo problemów, jeśli chodzi o jego sens i pełnioną przezeń funkcję w kontekście innych ważnych pojęć $c^{5}$. Dowodów na zasadność pytania, czym jest i co oznacza euthymia - dostarcza literatura przedmiotu, zwłaszcza przekłady tych fragmentów, w których owo pojęcie się pojawia. Za każdym razem można się spotkać $\mathrm{z}$ odmiennymi próbami tłumaczenia tego terminu ${ }^{6}$, co oczywiście ma niemały wpływ na interpretację danego fragmentu i myśli w nim zawartej, w konsekwencji zaś na zrozumienie ogólnego, o ile takie istnieje, przesłania Demokryta: co jest dla człowieka najważniejsze i jak wobec tego ma on wieść swoje życie, aby być naprawdę szczęśliwy.

Dlatego warto, jak się wydaje, poddać dokładnej filologicznej analizie wszystkie te fragmenty Demokryta, w których występuje zarówno rzeczownik $\varepsilon \dot{\theta} \theta v \mu i^{\prime} \alpha$, jak i pokrewne formy czasownikowe i przymiotniki, co, jak się wydaje,

którzy poświęcają je fillozofii. Obecny w tym pytaniu dylemat stanowi główny temat dialogu i tak naprawdę staje się sporem o to, czym jest dobro w życiu człowieka. Niemal identyczne pytanie

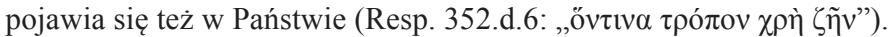

${ }^{2}$ Vide np. Reale 1993: 202; Gajda-Krynicka 2001: 477.

${ }^{3}$ To właśnie ono jest uznawane za „najwyższe dobro lub cel” (,a supreme good or goal, which he called 'cheerfulness' or 'well-being'"), jak pisze Taylor (1999: 227); identyczne sformułowanie powtarza on w: Long 1999: 197. Podobny pogląd wyraża Waterfield (2000: 170): „He [Democritus] was the first, as far as we know, to make a single aim - the attainment of 'contentment'"; także P.S. Hasper (w: Warren, Sheffield 2014: 223): ,some kind of goal consisting in a good condition of the soul".

Zupełnie inny pogląd prezentuje Kahn (1985: 26), twierdząc, iż koncepcję celu (jako dążenia do najwyższego dobra) 'narzucili' współczesnym badaczom doksografowie epoki hellenistycznej, interpretując myśl etyczną Demokryta przez pryzmat nauki Arystotelesa, sam zaś Abderyta w swoich wypowiedziach akcentuje przede wszystkim znaczenie rozumu w życiu człowieka: „But we need not follow the doxographers in attributing the Hellenistic concept of telos to a pre-Platonic moralist. An unprejudiced reading of the fragments does not support the view that Democritus' ethical thought is dominated by the pursuit of any single goal. And insofar as one principal preoccupation can be discerned throughout the fragments, it is a concern for reason in human life [...]".

${ }^{4}$ Oryginalną 'definicję' euthymia formułuje Farrar (1989: 220, przyp. 117): „euthumia is Democritus' term of art for flourishing, which in most writers is denoted by eudaimonia".

${ }^{5}$ Istotę problemu dobrze formułuje Johnson (2020: 214): „Democritus himself apparently glossed the term euthumiē with at least six other terms ... including the general term 'wellbeing' (euestō, $\varepsilon \dot{\varepsilon} \varepsilon \sigma \tau \omega$ ), as well as a series of negative terms, including 'not being disturbed' (ataraxia, $\dot{\alpha} \tau \alpha \rho \alpha \xi i \alpha) "$.

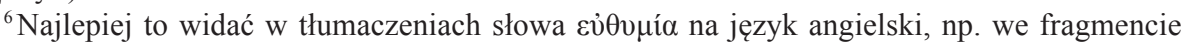
B 191: „,cheerfulness” (Taylor 1999: 25); ,,contentment” (Laks 2016: 261); „, la tranquillità dell'animo" (Enriques, Mazziotti 2016: 314). Vamvacas (2009: 229) natomiast podaje całą listę znaczeń euthymia: „felicity; cheerfulness; contentment; fine spirits; a good disposition; a "kind heart"”. 
pozwoli, po pierwsze, ustalić kontekstualne znaczenie nadrzędnego pojęcia, po drugie zaś - określić rolę, jaką pełni ono w myśli etycznej Abderyty. Ogółem

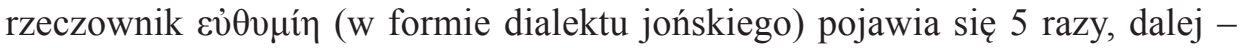

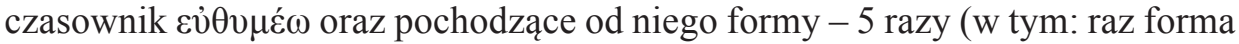
osobowa, a po dwa razy - bezokolicznik i imiesłowy), następnie - przymiotnik $\varepsilon u ̈ \theta v \mu \circ \varsigma-3$ razy (w tym raz w stopniu wyższym $\varepsilon \dot{\theta} \theta v \mu o ́ \tau \varepsilon \rho o v)$, wreszcie - par-

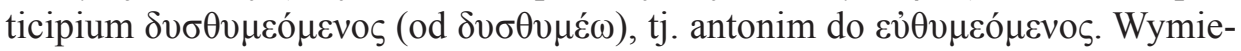
nione formy występują w 9 fragmentach, choć niektóre z nich na to miano nie zasługują, ponieważ są mniej lub bardziej interpretacjami tekstów starożytnych autorów, którzy, odnosząc się do twórczości danego myśliciela, rozumieli niektóre pojęcia obecne w nauce Demokryta przez pryzmat całej dotychczasowej spuścizny greckiej filozofii.

Za taki uznać należy fragment będący tytułem jednego z niezachowanych dzieł Demokryta o tematyce etycznej?:

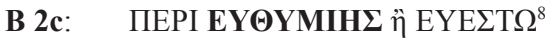

O pogodzie ducha albo Dobre usposobienie 9 .

Autorem, dzięki któremu wiemy najwięcej o samym Demokrycie i jego poglądach, jest Diogenes Laertios. To właśnie w jego dziele Żywoty i poglady stynnych filozofów, jedynego zachowanego z czasów starożytnych podręcznika historii filozofii, pojawia się nasze pojęcie jako tytuł w wykazie dzieł Abderyty:

Trazyllos sporządził katalog jego [Demokryta] dzieł, przy czym analogicznie do swego wykazu dzieł Platona podzielił je na tetralogie. Dzieła etyczne są następujące: [...] II. $O$ doskonałości męża, czyli o cnocie, Róg Amaltei, O pogodzie ducha, Zapiski etyczne, O dobrym samopoczuciu (nie udało się znaleźć). To są dzieła etyczne ${ }^{10}$.

U Diogenesa znajduje się także zdanie, które z pewnością miało decydujący wpływ na przekonanie nowożytnych uczonych, iż sedno Demokrytowej etyki polega na dążeniu człowieka do jednego tylko celu, jakim jest euthymia:

${ }^{7}$ C.C.W. Taylor przekonująco dowodzi (w: Rowe, Schofield 2008: $122 \mathrm{nn}$.), iż etyczne dzieła Demokryta (choć nie wspominają o nich ani Arystoteles, ani Teofrast), z których pochodzą zachowane fragmenty, były w obiegu jeszcze w I w. po Chr., kiedy żył Trazyllos, autor wspomnianego przez Diogenesa Laertiosa katalogu.

${ }^{8}$ Die Fragmente der Vorsokratiker..., 132. Wszystkie fragmenty w języku greckim Demokryta cytuję z tego właśnie zbioru.

${ }^{9} \mathrm{O}$ ile nie zaznaczono inaczej, thumaczenia tekstów greckich pochodzą od Autora.

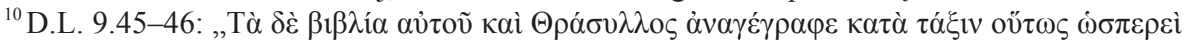

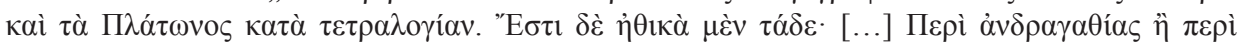

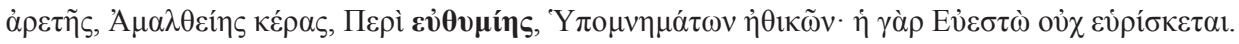

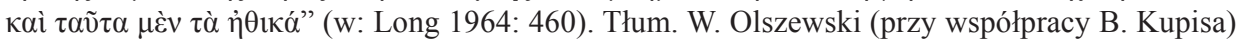
w: Krońska 1982: 541. 
Najwyższym celem jest pogoda ducha, nie pokrywająca się bynajmniej z rozkoszą, jak to niektórzy fałszywie interpretują, lecz będąca stanem spokoju i równowagi wewnętrznej, w którym dusza jest wolna od strachu, zabobonów i innych podobnych doznań; stan ten nazywa [Demokryt] albo dobrym samopoczuciem, albo innymi określeniami ${ }^{11}$.

Co jeszcze można wnosić z przekazu Diogenesa? Euthymia nie jest tym samym co rozkosz (ं் $\delta$ oví), polega na zachowaniu przez duszę spokoju wewnętrznego (tak jak spokojne jest niczym niezmącone morze, co sugeruje przysłówek $\gamma \alpha \lambda \eta v \tilde{\omega} \varsigma)$, dobrze i trwale zabezpieczonego ( $\varepsilon \dot{\sigma} \sigma \tau \alpha \theta \tilde{\omega} \varsigma)$, dzięki czemu duszy nie

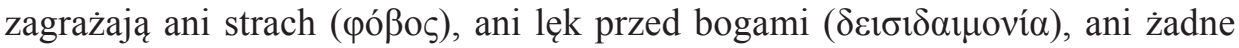
inne gwałtowne doznania. Istotną informacją jest ponadto pojawienie się sy-

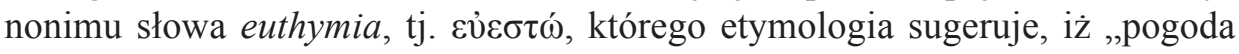
ducha” jest tożsama z „dobrym samopoczuciem”, kiedy nic nie zakłóca spokoju duszy i znajduje się ona w korzystnym dla niej, 'błogim' nastroju.

Więcej informacji na temat znaczenia słowa euesto znajdujemy we fragmencie B 140 zachowanym w leksykonie Hezychiusza. Oto jak antyczny leksykograf objaśnia to pojęcie: „dobre samopoczucie ... [to] szczęście, które bierze się z uporządkowania domu" 12 . Wydaje się zatem, że euthymia zestawiona tu z dwoma innymi rzeczownikami ( $\varepsilon \dot{\varepsilon \sigma \tau \omega ́, ~ \varepsilon v ̉ \delta \alpha \mu o v i ́ \alpha) ~ z n a c z n i e ~ p o s z e r z a ~ s w o ́ j ~}$ zakres znaczeniowy, bycie bowiem w dobrej kondycji duchowej (tożsamej z wewnętrzną, psychiczną strukturą człowieka) prowadzi do stanu szczęścia, ale takiego, który zapewniają duszy porządek, ład i spokój, jak w dobrze urządzonym i utrzymanym domu, w którym jego właściciel czuje się wygodnie i bezpiecznie.

Przekonajmy się więc, czy taką diagnozę potwierdzają kolejne wypowiedzi Demokryta. Pierwszą z nich stanowi fragment, w którym zamiast rzeczownika euthymie pojawia się pokrewny mu czasownik:

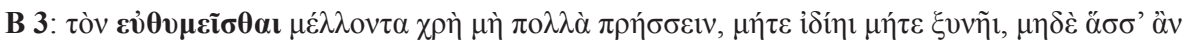

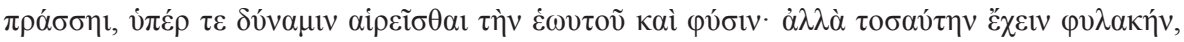

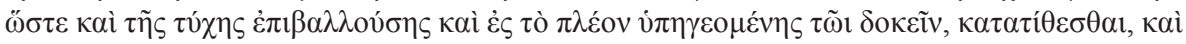

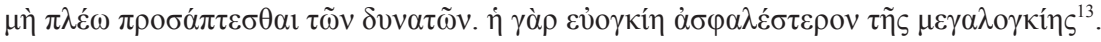

Kto chce być pogodny, nie powinien robić wielu rzeczy tak w życiu prywatnym, jak i publicznym, a jeśli zamierza coś czynić, nie może zabierać się za to, co przerasta jego możliwości i naturę. Przeciwnie, musi być tak czujny, że nawet gdy sprzyja mu fortuna i popycha do [realizacji] kolejnych celów, dzięki własnej decyzji bezpiecznie odkłada ją w depozyt i nie

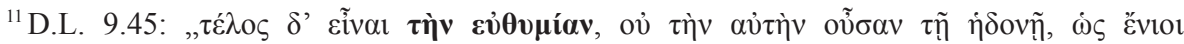

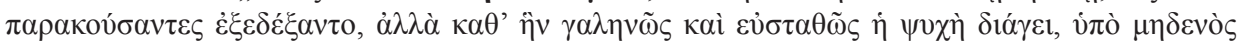

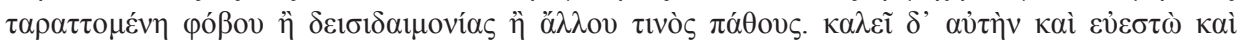

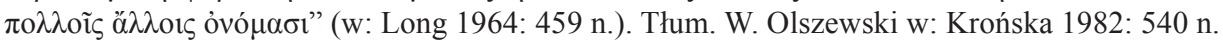

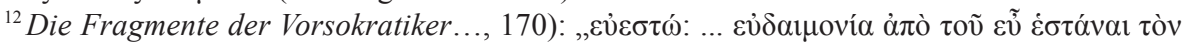

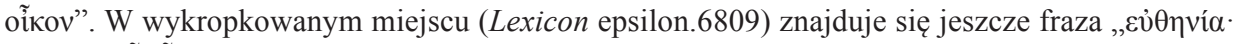

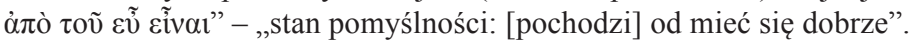

${ }^{13}$ Die Fragmente der Vorsokratiker..., $132 \mathrm{n}$. 
próbuje już czynić więcej, niż jest to możliwe. Wszak właściwa miara jest bezpieczniejsza od nadmiaru.

Demokryt najpierw odwołuje się do teoretycznej sytuacji, w której istotne znaczenie odgrywa ludzka wiedza. Kiedy bowiem człowiek do czegoś się zabiera, kiedy planuje przyszłe działania (co niewątpliwie sugeruje participium $\mu \varepsilon ́ \lambda \lambda o v \tau \alpha$ ), musi zachowywać się rozsądnie, używać rozumu i pamiętać przede wszystkim o ograniczeniach, jakie narzuca mu jego własna natura ( tj. organizm, struktura fizyczna i związane z nimi kondycja i wytrzymałość

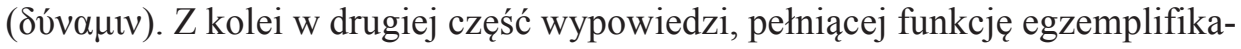
cyjną, człowiek staje w obliczu sprzyjającej mu fortuny, która nagle go dopada, przynosząc nie tylko doraźną korzyść, tu i teraz, ale roztaczając przed nim kuszącą perspektywę dalszych, jeszcze większych zysków. Jak wtedy należy się za-

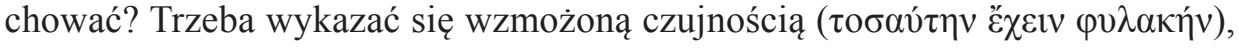
a następnie - opartym na znajomości analogicznych sytuacji przewidywaniem tego, co może się zdarzyć. Człowiek bowiem poddany zostaje trudnej, wyma-

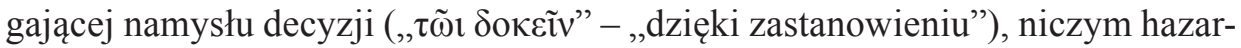

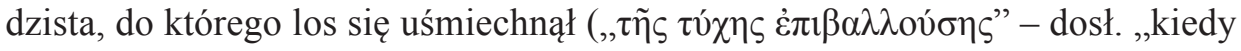
los [do niego] przybywa"), ale który zdaje sobie sprawę z tego, że w pewnym

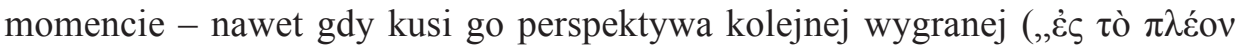

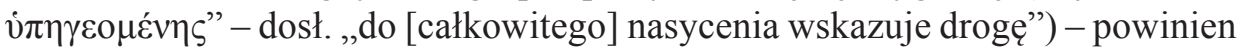
zrezygnować z dalszej gry, by cieszyć się tym, co już udało mu się zdobyć. Odkłada więc na bok złudną korzyść ( $\alpha \tau \alpha \tau i ́ \theta \varepsilon \sigma \theta \alpha)$ ), jaką roztacza przed nim los,

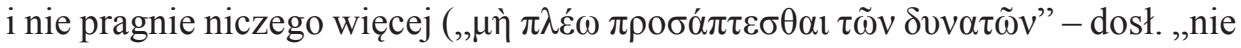
bierze się za więcej rzeczy niż te możliwe [do wykonania]"), ponieważ wie, że mógłby przekroczyć dozwoloną granicę i stracić wszystko ${ }^{14}$. Wypowiedź Demokryta wieńczy, jako konkluzja, gnomiczna myśl, która określa, jakie warunki

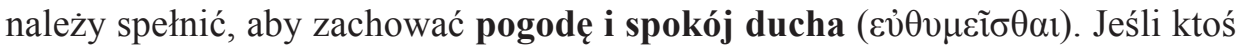
chce być szczęśliwy, pragnie zachować wewnętrzny spokój, nie może podejmować zbyt wielu działań i spraw, bez względu na to, czy dotyczą one jego sfery prywatnej (życia osobistego) czy publicznej - jako zaangażowanego politycznie

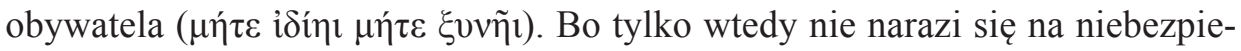

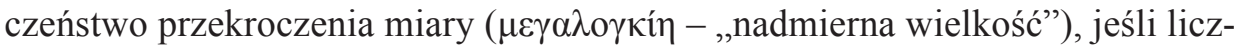

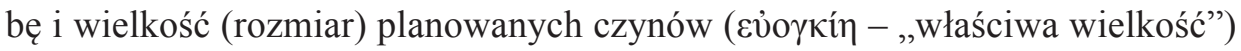
dostosuje do swoich predyspozycji i ograniczeń.

\footnotetext{
${ }^{14}$ Michaelides, Kardasi, Milios (2011) przywołują fragment B 3 jako przykład działalności ekonomicznej człowieka, której celem, zgodnie z zasadą „moderation”, jest „umiarkowana, materialna nagroda” (s. 4): „He [i.e. Democritus] stated that the (economic) actions of individuals should ... have as an end a moderate, and not an extreme, material reward”; podobnie na s. 5: „he believed that economic actions must have a moderate and not an extreme psychological reward", co oczywiście jest nawiązaniem do stanu pogody ducha, jaki człowiek osiąga dzięki zachowaniu umiaru w swoim postępowaniu.
} 
Warto tu wspomnieć, iż Plutarch w swoim dziełku O pogodzie ducha („Пєрì

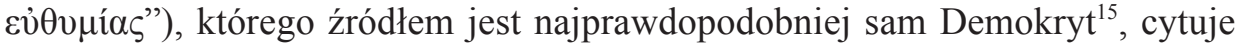
pierwszą część fragmentu B 3, w dość polemicznym i jednocześnie ironicznym - jak się wydaje - tonie, wyraźnie sugerując, iż Abderyta każe nam słono płacić za euthymia, skoro zapewnić ją może tylko brak działania $(\dot{\alpha} \pi \rho \alpha \xi i ́ \alpha)^{16}$ : „Ten więc, kto powiedział [Demokryt], że «kto chce być pogodny, nie powinien wiele działać ani w życiu prywatnym, ani publicznym», nade wszystko sprawia, że stan pogody ducha sporo nas kosztuje, bo można go kupić [jedynie] kosztem bezczynności" ${ }^{17}$. Z kolei żyjący po Plutarchu Klemens Aleksandryjski już w poważnym tonie pisze:

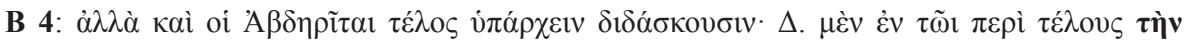

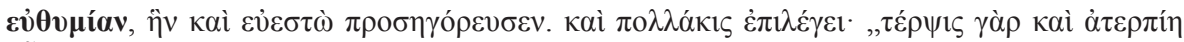

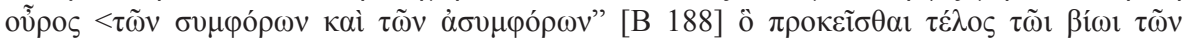

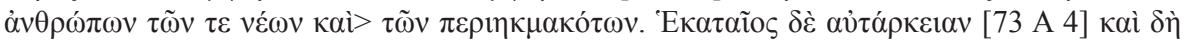

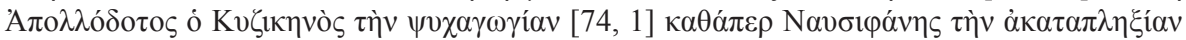

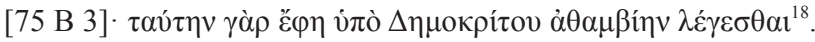

Lecz także abderyci przyjmują istnienie [jedynego] celu. Demokryt w swym traktacie $O$ celu [upatruje go] w spokoju ducha, który określił także mianem dobrego samopoczucia. Często jeszcze dodaje: „Przyjemność bowiem i nieprzyjemność jest oznaką tego, co korzystne i tego, co szkodliwe [pożytku i szkody]"19, a co stanowi cel dla życia tak młodych, jak i dojrzałych. Hekatajos zaś [za cel uważa] umiarkowanie, podczas gdy Apollodot z Kyzikos - pogodę ducha, podobnie jak Nauzifanes - spokój ducha, a właśnie ten ostatni - jak podaje Nauzifanes - przez Demokryta był nazywany niewzruszonością (= niezakłóconym stanem ducha).

Po pierwsze, Klemens przyjmuje tu istnienie traktatu, w którym, jak podpowiada jego tytuł, Demokryt miałby wyznaczyć najważniejszy dla życia człowieka cel, po drugie, identyfikuje ów cel z pojęciem euthymia, po trzecie, dodaje, iż Abderyta określał je zamiennie nazwą euesto (także innymi terminami), po

${ }^{15}$ Problemem zależności Plutarcha od Demokryta szczegółowo zajmuje się Hershbell (1982: 81-111). Kwestia ta stała się przedmiotem zainteresowania uczonych już znacznie wcześniej, bo pod koniec XIX wieku - vide Fowler 1890: 139-152. Równie wcześnie zaczęto kwestionować zależność Plutarcha od Demokryta, co najlepiej ilustruje artykuł Fairbanksa (1897: 75-87), w którym zupełnie pomija on Abderytę w wykazie przedsokratyków, obecnych w utworach Plutarcha.

${ }^{16}$ Dyskusję o tym, czy Demokryt był zwolennikiem (w kontekście cytowanego przez Plutarcha frg. B 3) „bezczynności” gwarantującej rzekomo osiągnięcie stanu euthymia - vide Hershbell 1982: $85 \mathrm{n}$.

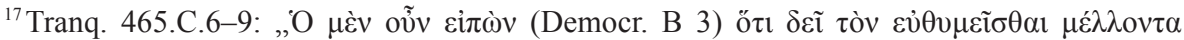

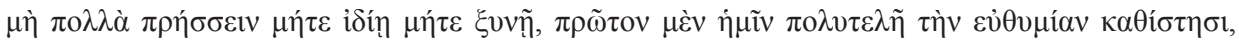

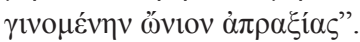

${ }^{18}$ Die Fragmente der Vorsokratiker..., 133 = Clem., Strom. 2.21.130.4-6.

${ }^{19}$ Zdanie to powtarza się (choć kolejność jego elementów jest inna) we fragmencie B 188 (Diels, Kranz 1956: 183): „ő (1960: 75-77) rozwiązuje długotrwałe zamieszanie dotyczące interpretacji we fragmencie B 4 pojęcia „przyjemności” (terpsis) jako kryterium u Demokryta. 
czwarte wreszcie, cytując fragment B 188, sugeruje, że owym celem jest dla fi-

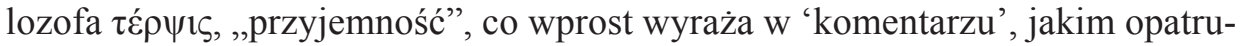
je przywołany fragment, bo - jak pisze - owa ,przyjemność” jest korzystna i dla

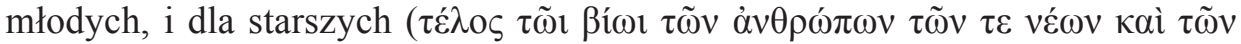
$\left.\pi \varepsilon \rho \eta \kappa_{\alpha} \alpha \kappa^{\tau} \omega v\right)$, czyli dla wszystkich. Nadto Klemens zestawia Demokrytowy cel, tj. „spokój ducha” (euthymia), z propozycjami innych filozofów natury ( $\tau \grave{\alpha}$

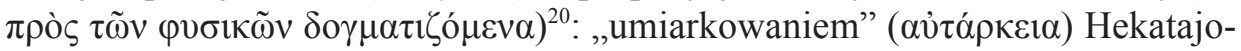
sa, ,pogodą ducha” ( $\psi v \chi \alpha \gamma \omega \gamma i ́ \alpha)$ Apollodota z Kyzikos (właściwie Apollodora) ${ }^{21}$ i ,,spokojem ducha” ( $\left.\dot{\alpha} \kappa \alpha \tau \alpha \pi \lambda \eta \xi \dot{i} \alpha\right)$ Nauzifanesa, dodając, iż Abderyta używał na określenie ostatniego terminu - słowa $\alpha \theta \alpha \mu \beta \eta^{22}{ }^{22}$, które można rozumieć jako ,niczym niezakłócony stan ducha”. Wszystkie te nazwy są jakby synonimami $^{23}$, które w mniej lub bardziej udany sposób oddają stan, w jakim znajduje się człowiek (lepiej zaś jego dusza), przez nic i nikogo nie niepokojony, cieszący się tym, co ma pod ręką, mający poczucie bezpieczeństwa, trwający w swoistym błogostanie, równoznacznym z zadowoleniem lub nawet szczęściem²4.

Przywołane dotąd źródła należy traktować jako testimonia, które nie tyle wyjaśniają znaczenie słowa euthymia, ile raczej są subiektywnymi świadectwami, pokazującymi, jak różnie w tradycji doksograficznej to pojęcie pojmowano i jakimi innymi terminami próbowano je objaśniać. $Z$ pewnością starożytni (jak i współcześni badacze) nie mieliby problemów ze zrozumieniem słowa euthymia w kontekście myśli etycznej Demokryta, gdyby w całości przetrwały poświęcone jej dzieła. Niestety, zachowały się tylko ich okruchy, choć trzeba przyznać, że w przypadku Abderyty jest ich stosunkowo dużo w porównaniu z innymi przedsokratykami. Najwięcej wypowiedzi filozofa odnosi się do zagadnień etyczno-psychologicznych ${ }^{25}$ (w tym sporą część stanowią sentencje

${ }^{20} \mathrm{~W}$ XXI rozdziale Kobierca II, poświęconym różnym poglądom filozofów na cel człowieka i jego najwyższe szczęście.

${ }^{21}$ Vide Die Fragmente der Vorsokratiker..., 246.

${ }^{22}$ Pojawia się ono jeszcze raz w zachowanym w Antologii Stobajosa (3.7.31) fragmencie B

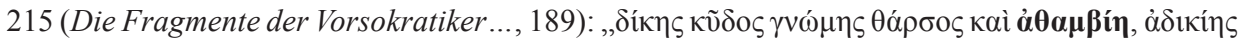

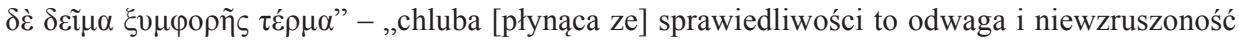
myśli (niezmąconość umysłu), strach natomiast [biorący się z] niesprawiedliwości [ma swój] kres w nieszczęściu”.

${ }^{23}$ Które należy po raz kolejny traktować jako utrwalony przez hellenistyczną doksografię, ‘wypaczony' obraz ważnego w myśli etycznej Demokryta pojęcia euthymia.

${ }^{24}$ Johnson (2020: 234) przedstawia całą rodzinę związanych z euthymia pojęć, dzieląc ją na dwie części: „The terms used by Democritus break down into two groups, positive and negative”, w tym ta druga ,with the alpha-privative prefix (meaning „,not”)".

${ }^{25}$ Chociaż Demokryt oferuje nam znacznie więcej wypowiedzi z zakresu filozofii moralnej niż inni przedsokratycy (tym, który z nim może 'konkurować', jest tylko Heraklit), niektórzy uczeni są bardzo podejrzliwi w kwestii autentyczności tych fragmentów, które - ich zdaniem trudno pogodzić z atomistyczną fizyką Abderyty. Wśród szeroko dyskutujących o tym problemie są m.in.: Vlastos (1945: 578-592); Vlastos (1946: 53-64); Guthrie (1965: 489-492); Edmunds (1972: 342-357); Kahn (1985: 1-31); Warren (2002). 


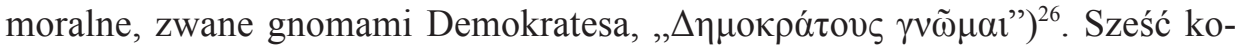
lejnych fragmentów ${ }^{27}$, które poddane zostaną analizie ze względu na obecność euthymia i słów jej pokrewnych, dotyczy właśnie problematyki człowieka i jego zachowań w otaczającym go świecie.

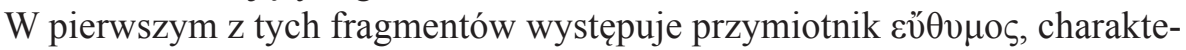
ryzujący właściwą postawę człowieka wobec prawa i sprawiedliwości:

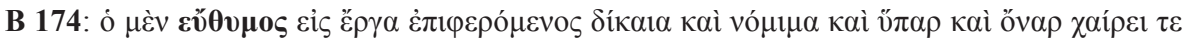

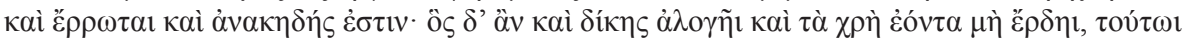

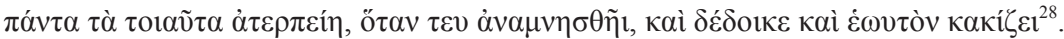

Człowiek o pogodnym usposobieniu, kiedy podejmuje sprawiedliwe i zgodne z prawem czyny, tak w dzień, jak i w nocy [= zawsze] odczuwa nie tylko radość, lecz także nabiera energii i uwalnia się od trosk. Natomiast w człowieku, który nie ma poczucia [nie zna] sprawiedliwości i nie wypełnia swoich obowiązków, wszystkie te rzeczy budzą wstręt, ilekroć o którejś z nich sobie przypomni, co więcej, żyje w strachu i krzywdzi samego siebie.

Wypowiedź Demokryta można podzielić na dwie części. W pierwszej udziela on odpowiedzi na dwa pytania: (1) jakie warunki należy spełnić, aby zasłu-

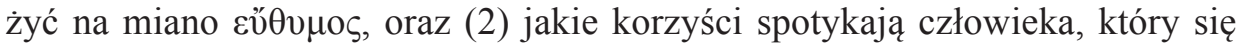
do tych wymogów dostosuje. Druga część przedstawia sytuację odwrotną: co może przydarzyć się temu, kto postępuje zupełnie inaczej, wbrew zaleceniom Abderyty. Jak można zatem opisać obie postawy? Preferowany sposób polega na zachowaniu adekwatnym do obowiązujących przepisów prawa. Należy podejmować się tylko tych spraw ("̌ppo), które są zarówno sprawiedliwe (na mocy ogłoszonych aktów prawnych), jak i zgodne z niepisanymi normami, opartymi

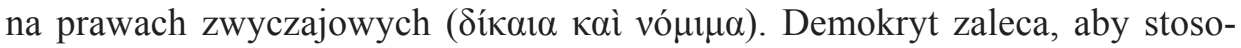
wać i konwencjonalne, umowne prawa, i te tradycyjne, niepisane, zwyczajowe. Krótko mówiąc, jeśli człowiek działa sprawiedliwie, godząc tradycję z konwencją (prawem stanowionym), wtedy osiąga - jako bonus - taki stan egzystencji, w którym, po pierwsze, ogarnia go radość ( $\chi \alpha i ́ p \varepsilon \imath)$, po drugie, w jej rezultacie

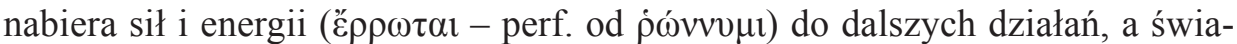

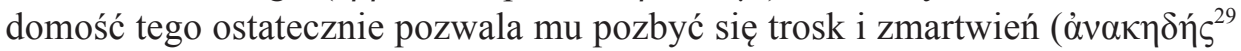
$\dot{\varepsilon} \sigma \tau \imath v)$. Dokonać zaś tego wszystkiego zdolny jest tylko ten, kto nosi miano $\boldsymbol{\varepsilon} \tilde{v} \theta \boldsymbol{v} \mu \boldsymbol{s}$, czyli człowiek o pogodnym usposobieniu, posiadający taką strukturę mentalną i duchową, dzięki której nadaje swemu życiu optymalny kształt. Nie

${ }^{26}$ Zebrali je Diels, Kranz (Die Fragmente der Vorsokratiker..., 153-165).

${ }^{27}$ Wszystkie pochodzą z Antologii (Florilegium) Stobajosa (1. poł. V w. po Chr.), w którego dziele zachowała się znaczna część pozostałości z dzieł Demokryta; co więcej, Stobajosa uznaje się za pewniejsze od innych źródło, jeśli chodzi o wiarygodność cytowań z Demokryta (o ile wcześniej dany fragment już przypisano Abderycie) - vide: Farrar 1989: 193; Taylor (w: Rowe, Schofield 2008: 124).

${ }^{28}$ Die Fragmente der Vorsokratiker..., $179 \mathrm{n}$.

${ }^{29}$ Przymiotnik ten to hapax legomenon w zachowanych greckich tekstach literackich. 
mógłby jednak tego urzeczywistnić bez znajomości prawa. Wiedza zatem okazuje się kluczem do sukcesu, tak jak jej brak prowadzi do nieszczęścia, które

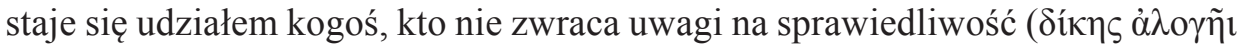
- dosł. „nie rozumie”), bo jej nie zna i dlatego nie wykonuje tego, co do niego

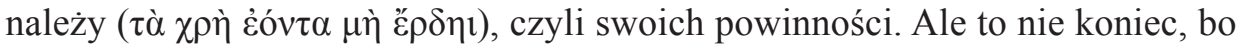
jeszcze większy dramat przeżywa on wtedy, kiedy do akcji wkracza jego władza pamięci, zdolność przypominania sobie ( $\alpha \dot{ } \alpha \mu \nu \eta \sigma \theta \tilde{\eta} \mathrm{l})$, która, przywołując, na-

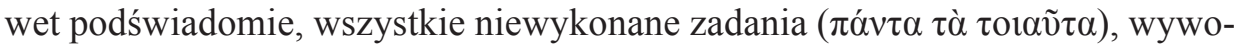
łuje w nim wstręt ( $\alpha \tau \varepsilon \rho \pi \varepsilon i ́ \eta)$, stan niepożądany, bo pozbawiony jakiejkolwiek przyjemności. Co więcej, poważnym jego następstwem jest niepokój przeradzający się w strach ( $\delta \varepsilon ́ \delta o 1 \kappa \varepsilon)$, który skutecznie paraliżuje pracę rozumu, w ten sposób odbierając człowiekowi trzeźwy osąd sytuacji, w jakiej się znalazł pod wpływem niekontrolowanej fali złych emocji. W rezultacie człowiek, ulegający takim doznaniom, sobie samemu wyrządza krzywdę $(\dot{\varepsilon} \omega v \tau \text { òv } \kappa \alpha \kappa i \zeta \zeta \varepsilon 1)^{30}$.

Demokryt zatem, w świetle dokonanej analizy, przedstawia dwie skrajne postawy: z jednej strony człowieka świadomego, który wie, jak postępować (bo zna zasady) i dlatego zachowuje pogodę ducha ${ }^{31}$, z drugiej zaś takiego, który sprawiedliwości (prawa) nie zna i nie wypełnia swoich obowiązków, a ich wspomnienie budzi odrazę i strach wraz z subiektywnym poczuciem doznanej krzywdy.

Z zaskakującym i nieco zagadkowym do interpretacji przykładem człowieka sprawiedliwego mamy do czynienia w kolejnej wypowiedzi Abderyty:

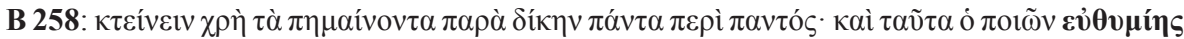

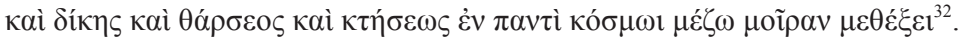

Przede wszystkim należy zabijać wszystkie te stworzenia, które wbrew prawu wyrządzają krzywdę $^{33}$. Dlatego ten, kto tak czyni, w każdym porządku [politycznym] zdobędzie większy udział w szczęściu, sprawiedliwości, odwadze i posiadaniu.

Człowiek, jak widać, może doznać krzywdy nie tylko od siebie samego, jakby z własnych rąk, świadomie bądź nie. Wyrządzić ją może coś lub ktoś

${ }^{30}$ Nie podzielam opinii Kahna (1998: 35), który dostrzega w tym końcowym sformułowaniu przejaw niepokoju sumienia: „Democritus does not tell us what the unjust man will be afraid of, but clearly his conscience is unquiet". W moim przekonaniu jest to efekt braku nadzoru ze strony rozumu, który traci kontrolę nad strachem i boi się wywołanego przezeń, wewnętrznego chaosu w duszy człowieka. Nie zgadzam się też z tłumaczeniem "so he is afraid and reproaches himself” (Johnson 2020: 229), suponuje ono bowiem, iż człowiek pod wpływem strachu może w pełni świadomie czynić sobie wyrzuty z powodu złego postępowania.

${ }^{31}$ Cf. Johnson 2020: 229.

${ }^{32}$ Die Fragmente der Vorsokratiker..., 197.

${ }^{33}$ B. Kupis, kiedy tłumaczy to zdanie: „Za wszelką cenę trzeba zabijać tych, którzy wbrew prawu wyrządzają krzywdę" (Kupis 2004: 369) - ma chyba na myśli ludzi, z czym nie można się zgodzić ze względu na użyte w neutrum substantywizowane participium $\tau \dot{\alpha} \pi \eta \mu \alpha i ́ v o v \tau \alpha$, stanowiące przedmiot czynności zabijania. 
z zewnątrz, czego przykładem jest substantywizowany imiesłów w rodzaju nijakim $\tau$ à $\pi \eta \mu \alpha i ́ v o v \tau \alpha$, który odnosi się do jakichś stworzeń czy zwierząt (,wyrządzające szkodę, popełniające przestępstwo"), co oczywiście wyklucza ludzi jako desygnat tej nazwy. Skoro więc istnieją istoty, które nie znają prawa

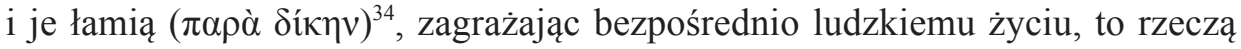
konieczną jest każdego szkodnika bezwzględnie (,, „wszystkie [istoty] nade wszystko”) eliminować, czyli „zabijać”. O obowiązku takiego działania świadczy nie tylko nieosobowe „trzeba” ( $\chi \rho \eta ́)$, lecz także zamierzona, jak się wydaje, aliteracja, której obecność na końcu pierwszego

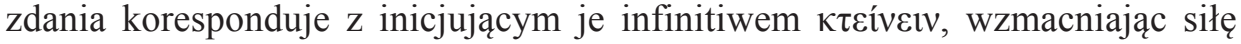
przesłania Filozofa: „zabijać .... wszystkie nade wszystko”, podobnie zresztą

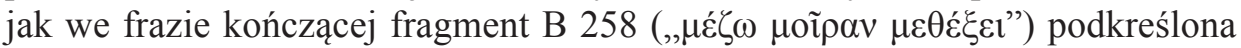
została korzyść. Ten bowiem, kto tak postępuje ( $\tau \alpha \tilde{\tau} \tau \alpha$ ó $\pi$ ol $\tilde{\omega} v)$ może liczyć ze strony państwa na znaczną nagrodę, zasłużony, większy (od innych, którzy tego nie czynią) udział ( $\mu \varepsilon \dot{\zeta}(\omega$ ooĩpav) nie tylko w euthymii, lecz także w towarzyszących jej cnotach: sprawiedliwości i odwadze ( cej, taki człowiek nabywa też większe prawo do posiadania dóbr materialnych ( $\tau \tau \dot{\sigma} \sigma \varepsilon \omega \varsigma)$, takie zaś zachowanie i takie nagrody winny obowiązywać w każdym porządku (غ่v $\pi \alpha v \tau i ̀ ~ \kappa o ́ \sigma \mu \omega t)$ [ustroju politycznym].

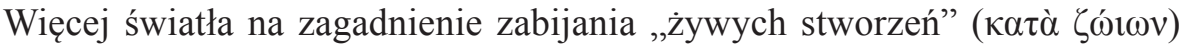
rzucają dwa inne, cytowane również przez Stobajosa ${ }^{35}$ fragmenty: B 257 i B 259, pomiędzy którymi znajduje się B 258 . W pierwszym z nich Demokryt postuluje bezkarne eliminowanie istot szkodzących ze względu na „dobre samopoczucie”

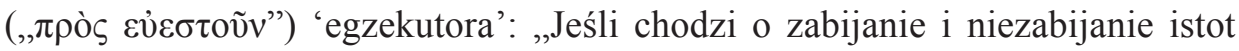
żywych, obowiązują następujące zasady: kto zabija te, które czynią krzywdę lub mają taki zamiar, jest niewinny, a ze względu na dobrostan (spokój ducha) lepiej jest tak czynić niż nie [czynić]" ${ }^{\prime 3}$. Z kolei we fragmencie B 259 Filozof otwarcie zasadę tę odnosi do ludzi: „Tak jak jest zapisane [ustanowione] o dzikich bestiach i gadach, w ten sam sposób, jak sądzę, należy traktować ludzi. Zgodnie z ojczystymi prawami [należy] zabijać wroga w każdym porządku [politycznym], w którym prawo [tego] nie zakazuje. Jednak zabraniają tego miejscowe przepisy religijne, przymierza [traktaty] i przysięgi" ${ }^{\prime 3}$.

${ }^{34}$ Nie zgadzam się z thumaczeniem, jakie proponuje P. Curd (Preus 2001: 155): „It is right to kill anything contrary co justice", co wyraźnie sugeruje, że wbrew prawu działa ten, kto zabija „wszystko" (= anything).

${ }^{35} \mathrm{~W}$ jego Antologii w rozdziale dot. praw i zwyczajów: IV 2.15-18.

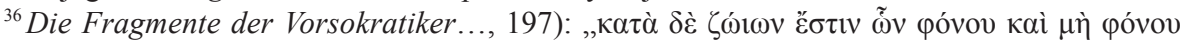

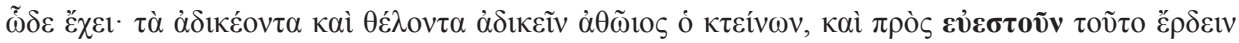

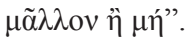

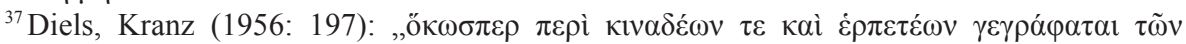

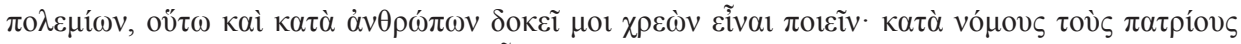

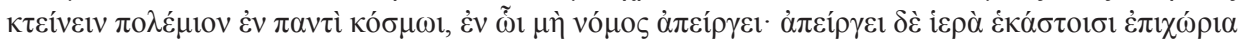

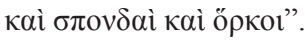


Wszystkie te fragmenty, jak określił to J.F. Procopé i z czym wypada się zgodzić, ,zdumiewają najbardziej” w zachowanej spuściźnie Demokryta ${ }^{38}$. Nasze zdumienie może budzić sposób zachowania ludzi, którzy, jak przekonuje Abderyta, dla dobra własnych poleis - kierując się prawem przodków i prawem stanowionym - powinni kategorycznie ${ }^{39}$ pozbywać się zarówno żywych stworzeń (zwierząt), jak i osób, zważywszy na duże zagrożenie $\mathrm{z}$ ich strony, szkody przez nie wyrządzane, a nawet utratę życia. Tak drastyczne środki pomagają jednak zachować każdy porządek polityczny (państwo) ${ }^{40}$, obywatelom zaś, którzy je stosują i „,czynią to, co trzeba”41 , w pierwszej kolejności przynoszą w nagrodę większy „,spokój ducha” (euthymia), dalej - inne wspomagające go cnoty (sprawiedliwość, odwagę), na końcu zaś dobra doczesne. Te ostatnie nie są bynajmniej najważniejsze, o czym zapewnia Demokryt we fragmencie B 189:

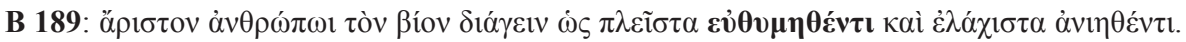

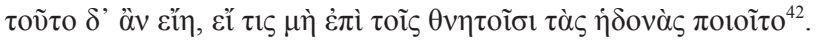

Najlepszą rzeczą jest dla człowieka, aby spędzał życie w stanie jak największego zadowolenia i jak najmniejszego zasmucenia. A stać się to może wtedy, jeśli nie będzie on szukał przyjemności w rzeczach przemijających.

We fragmencie tym znajduje się kolejna wskazówka, dzięki której łatwiej można dostrzec naturę i sens pojęcia euthymia. W świetle bowiem omówionych już fragmentów, na jego znaczenie składają się: 1. Właściwy umiar w zakresie działalności prywatnej i publicznej (B 3); 2. Umiejętność dostosowania do własnej natury, tj. możliwości swojego organizmu (B 4); 3. Znajomość prawa i zgodne z nim postępowanie (B 174); 4. Eliminowanie krzywdzicieli i wrogów państwa, oraz 5. Utrzymanie duszy w dobrej kondycji, w stanie 'błogostanu' (zob. euesto w B 3). Pierwszy, trzeci i czwarty warunek dotyczą wymiaru zewnętrznego, mikro- i makrokosmosu, w jakim człowiek żyje i funkcjonuje,

${ }^{38}$ Procopé (1989: 311): „These fragments are amongst the most bewildering in the whole corpus Democriteum".

${ }^{39}$ Johnson (2020: 229) zauważa, iż Demokryt wyklucza tu postawę neutralną: „Democritus again precludes a neutral stance whereby one might enjoy the wanted psychological state, euthumiē, without deliberately and consciously acting justly and legally".

${ }^{40}$ Procopé (1989: 312) zauważa, iż cytowane trzy fragmenty (B 257-259), w których mowa jest o wyjętych spod prawa osobach i zwierzętach, wyrządzających lub mających tylko zamiar wyrządzać krzywdę, dotyczą ochrony wspólnego bezpieczeństwa: „these Democritean pronouncements on killing outlaws and destroying animals which do or may do damage are concerned with protecting the common security".

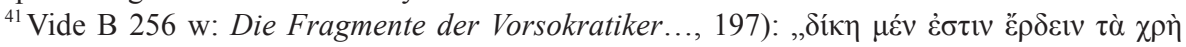

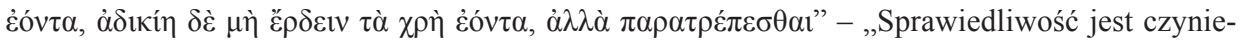
niem tego, co trzeba, a niesprawiedliwość nie jest czynieniem tego, co trzeba, ale unikaniem [działania]".

${ }^{42}$ Die Fragmente der Vorsokratiker..., 183. 
natomiast drugi i piąty odnoszą się do jego wewnętrznej struktury psychofizycznej. Teraz dołącza się kolejne kryterium, tj. optymalny stan zadowolenia i zredukowanie do minimum jego przeciwieństwa - smutku.

Aby doprowadzić do modelowej sytuacji, w której złe (szkodliwe) uczucie ustępuje miejsca dobremu (korzystnemu), Demokryt używa dwóch superlatiwów: pierwszy, urobiony od $\pi$ o $\lambda$, określa stopień najwyższego zadowolenia

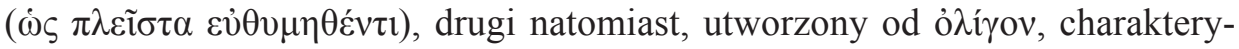

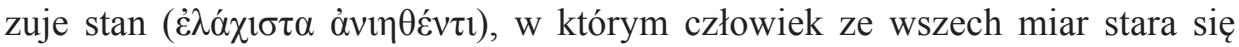
ograniczyć obecność i oddziaływanie smutku (i podobnych uczuć). Paradoksalnie więc dwa wyrażenia: „najwięcej” i ,najmniej” prowadzą do sformułowania

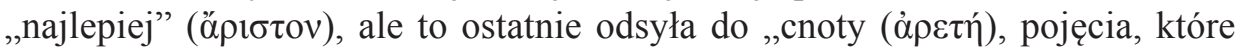
sugeruje bliską relację czy może nawet tożsamość z euthymia, stanem ,pogody ducha", obecnym tu w formie participium aoristi passivi (

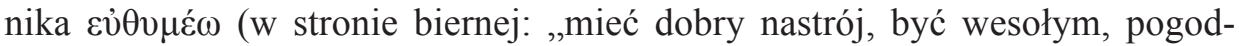
nym") ${ }^{43}$. Kiedy więc można taki stan osiągnąć? Odpowiedź Demokryta zaskakuje zwięzłością wyrażenia i zawartą w nim prostotą działania. Posługując się okresem możliwości (modus potentialis), Abderyta daje człowiekowi receptę, jak powinien żyć, aby i teraz, i w przyszłości „mieć się dobrze” na duchu. To

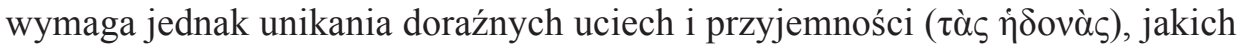
dostarczają rzeczy przemijające ( $\tau$ oĩ $\theta v \eta \tau o i ̃ \sigma))^{44}$, równoznaczne z czymś materialnym, doczesnym, nietrwałym, ulotnym, do czego - zdaniem filozofa - nie należy się ani przywiązywać, ani tym bardziej uzależniać od tego własnego szczęścia $^{45}$. Po jednej stronie mamy więc „dobry nastrój, pogodę ducha” jako niezbędny warunek cnoty, po drugiej zaś - przelotne, przyjemne chwile, słodkie uciechy, których źródłem są rzeczy materialne, zależne i od kapryśnej fortuny, i od zmiennych uczuć, jakim poddaje się ten, kto żyje tylko chwilą, komu bardziej zależy na doraźnej ułudzie niż długotrwałym szczęściu, opartym na świadomym, racjonalnym działaniu. Co więcej, jak się wydaje, implicite fundamentem

\footnotetext{
${ }^{43}$ Montanari (2015: 848) przywołuje fragment B 189 Demokryta (i formę part. aor. pass.), samemu zaś czasownikowi nadaje znaczenia: „to be of good humor, to be cheerful, serene”.

${ }^{44}$ Johnson (2020: 226) zawęża „rzeczy przemijające” („mortal things”) do „the traditional triad of food, drink, and sex”, z czym nie do końca się zgadzam, nawet jeśli punktem odniesienia jest fragment B 235, a zwłaszcza zdanie: „ő

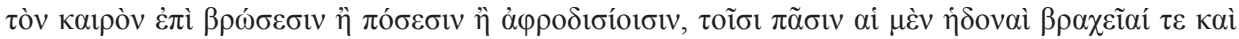

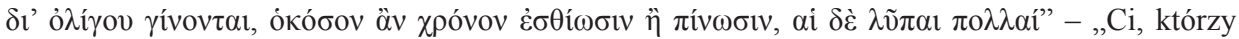
czerpią przyjemności z żołądka, przekraczając miarę w jedzeniu, piciu i rozkoszach miłosnych, doznają krótkotrwałych i ulotnych uciech, utrzymujących się tak długo, jak długo jedzą i piją, przynoszących jednak wiele przykrości”. Podobnie jak Johnson uważa Wolfsdorf (2013: 14): „By 'tak[ing] pleasure in mortal things' I understand Democritus to mean indulging in what he elsewhere calls "pleasures of the belly", powołując się na ten sam fragment B 235.

${ }^{45}$ Trudno zatem zgodzić się ze stwierdzeniem, którego autorem jest C.C.W. Taylor (w: Long 1999: 197), iż Demokryt zaleca życie w „umiarkowanym hedonizmie” („recommendation to a life of moderate, enlightened hedonizm").
} 
takiego życia jest rozum, bo tylko dzięki niemu człowiek może w pełni panować nad emocjami tak, by jak najdłużej cieszyć się ,pogodą ducha”. Inaczej mówiąc, Abderyta nie ceni rzeczy materialnych, bo to w nich właśnie upatruje źródło zła, skoro ostatecznie zamiast poczucia prawdziwego dobra i szczęścia wywołują w nas smutek, frustrację i przygnębienie zaraz po tym, jak się kończą. Dlatego tak ważne jest opanowanie, rozsądek i mądre działanie, dzięki którym życie człowieka, pozbawione destrukcyjnego wpływu złych uczuć, staje się stabilne, harmonijne i dobre, w rezultacie zaś spędzone pogodnie, w stanie największego zadowolenia ( $\dot{\varsigma} \pi \lambda \varepsilon \tilde{\imath} \sigma \tau \alpha \varepsilon \dot{v} \theta v \mu \eta \theta \dot{\varepsilon} v \tau \imath)$.

Znacznie szerzej wątek ten został rozwinięty w najdłuższym w zachowanej spuściźnie Demokryta fragmencie ${ }^{46}$ :

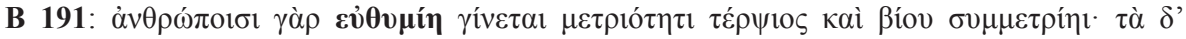

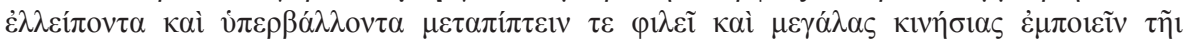

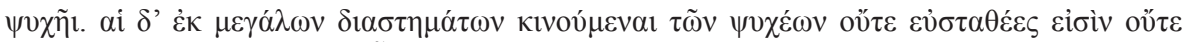

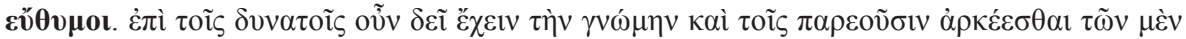

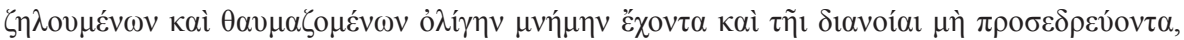

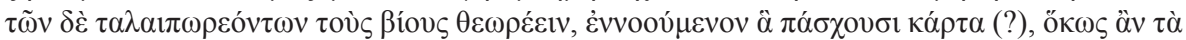

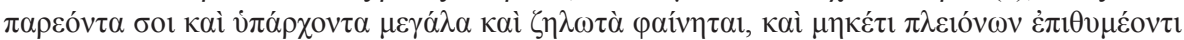

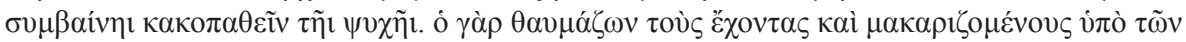

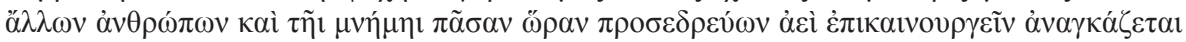

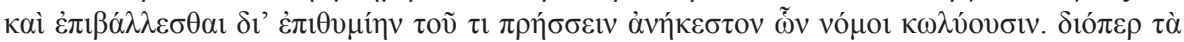

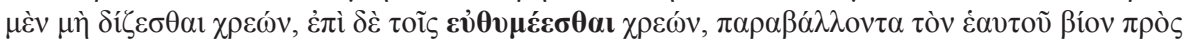

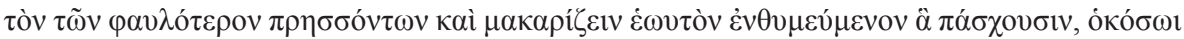

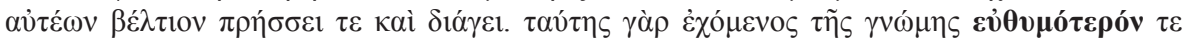

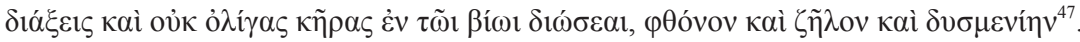

Pogoda ducha wśród ludzi rodzi się bowiem z umiaru w przyjemności i z harmonii w życiu. Niedobory i nadmiary mają zwyczaj przechodzić na przemian jedne w drugie i wywołują w duszy ogromny zamęt. Te więc dusze, które poruszają się między przeciwnymi sobie stanami, nie są ani spokojne, ani pogodne [szczęśliwe]. Dlatego trzeba skupiać się na tym, co jest możliwe [do osiągnięcia] i zadowalać się tym, co jest [w naszym zasięgu], nie poświęcając zbyt wiele czasu rzeczom, które są przedmiotem zazdrości czy podziwu, i nie zwracając na nie uwagi. Należy raczej patrzeć na życie nieszczęśliwych, zastanawiając się nad tym, jak bardzo cierpią, abyś mógł pojąć, że [twoja] obecna kondycja i stan posiadania są czymś wielkim i godnym zazdrości, i aby już dłużej - z powodu nadmiernych pragnień - [twoja] dusza nie była narażona na cierpienie. Kto bowiem podziwia bogaczy, których inni uważają za szczęśliwych, i przez cały czas o nich myśli, ten jest zmuszony wciąż podejmować nowe wyzwania i usilnie pragnie, $\mathrm{z}$ chęci żądzy, popełnić jakiś niedający się naprawić czyn, który prawo zabrania. Dlatego o pewne rzeczy nie przystoi [mu] zabiegać, lecz winien cieszyć się

${ }^{46}$ Johnson (2020: 223) zauważa, iż „it is possible that B 191 followed B 3 either immediately or after only a small gap” - jako ciąg dalszy i wyjaśnienie zdania, którym kończy się B 3: „Wszak właściwa miara jest bezpieczniejsza od nadmiaru”. Równie interesujący jest podział całego fragmentu B 191 na pięć sekcji oraz wyodrębnienie w jego strukturze trzech entymematów (Johnson 2020: 224); Johnson (2014: 10-12) już wcześniej poddał analizie B 191, dzieląc fragment na dwie części (a i b).

${ }^{47}$ Die Fragmente der Vorsokratiker..., $184 \mathrm{n}$. 
tym, co jest [pod ręką], porównując swoje życie do życia tych, którym wiedzie się gorzej, powinien też uważać się za szczęściarza, zdając sobie sprawę z tego, ile tamci cierpią i o ile lepiej od nich mu się powodzi i wiedzie swoje życie. Jeśli więc mocno będziesz trzymał się tej myśli, przeżyjesz swoje życie o wiele bardziej pogodny [szczęśliwy] i usuniesz z niego niemało zgubnych dla życia przypadłości, [także] zazdrość, [niegodziwą] rywalizację i wrogość.

Wydaje się, że poprzedni fragment B 189 stanowi doskonałe preludium do tego, co ma miejsce w tej dłuższej wypowiedzi, będącej obszernym komentarzem i jednocześnie szczegółową instrukcją dla człowieka, do którego Demokryt zwraca się bezpośrednio, używając drugiej osoby, obecnej w datiwie

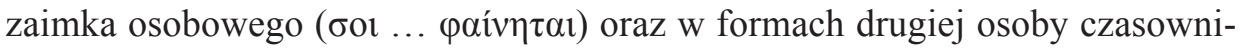
ków: $\delta \mathfrak{i \alpha ́ \xi \varepsilon 1 \zeta ~ . . . ~ \delta i \omega ́ \sigma \varepsilon \alpha ı ~ o s t a t n i e g o ~ z d a n i a ~ f r a g m e n t u . ~ N i e ~ s p o s o ́ b ~ u s t a l i c ́ , ~ k o g o ~}$ Filozof ma na myśli, czy chodzi o konkretną, znaną mu osobę, czy też jest to uogólnienie odsyłające do każdego potencjalnego odbiorcy - czytelnika jego pouczenia. Można tylko przypuszczać, że Demokrytowi bardziej zależało na dotarciu ze swoim przesłaniem do jak najszerszego kręgu odbiorców. Abderyta rozpoczyna je od generalnego stwierdzenia, które wyraża jego osobisty pogląd na to, kiedy i jak powstaje oraz od czego zależy euthymia, a także jaki wpływ na „pogodę ducha” wywiera dusza (psyche). Śmiało chyba można ten trzyzdaniowy wstęp określić jako supozycję, z jaką w dalszym ciągu wywodu mierzy się filozof, usiłując na konkretnym przykładzie udowodnić jej prawdziwość. Oto bowiem stwierdza, że „pogoda ducha” powstaje dzięki ,umiarowi w [doznawa-

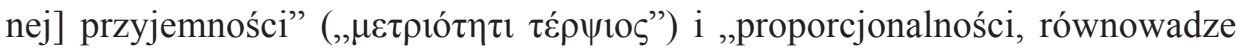

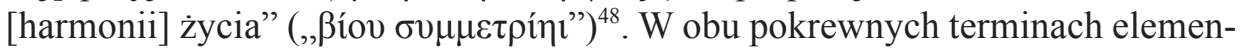
tem konstytucyjnym jest „miara” ( $\mu \varepsilon ́ \tau$ ¿ $\rho \circ$ ), i to z domyślnym epitetem - słuszna, właściwa, odpowiednia, zestrojona, co zresztą wyraźnie sugeruje prefiks $\sigma v v-$ w rzeczowniku $\sigma u \mu \mu \varepsilon \tau$ pí i co od razu przywołuje Solonową regułę „nic po-

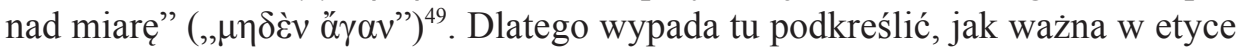
Demokryta jest równa miara, chciałoby się powiedzieć - używając terminologii Arystotelesa - złoty środek jako stan, który jest równowagą pomiędzy niedomiarem a nadmiarem ${ }^{50}$.

${ }^{48}$ Johnson (2020: 224) tłumaczy, iż „równowaga w życiu”, z której rodzi się euthymia, polega na współmierności, dostosowaniu się człowieka do własnej natury i możliwości: „euthumiē is produced by 'moderate enjoyment' and by living a way of life that is 'commensurate' with one's nature and capabilities".

${ }^{49}$ Aforyzm ten widniał u wejścia do świątyni Apollona w Delfach obok innego, nie mniej

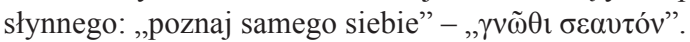

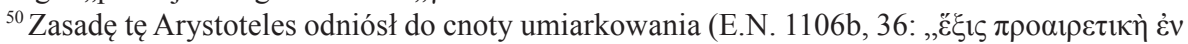

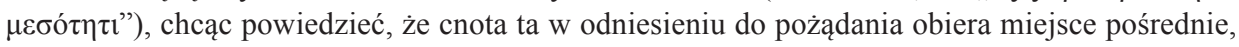
aby człowiek nie stał się rozpustny, ale także nie zalecając mu przesadnej wstrzemięźliwości.

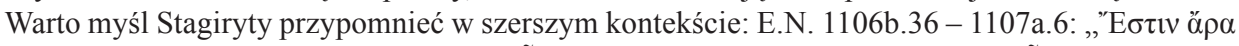

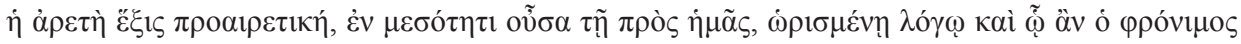

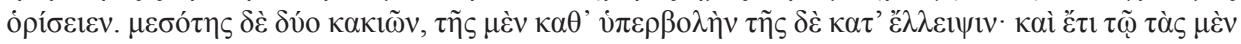

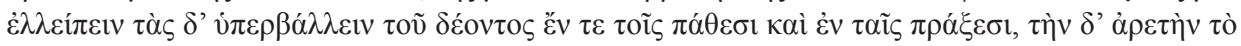


Podobnie myśli Abderyta, kiedy w drugim zdaniu zauważa, że rzeczy, któ-

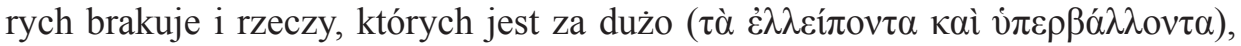
mają stałą skłonność do zmiany ( $\mu \varepsilon \tau \alpha \pi i ́ \tau \tau \varepsilon เ v$ $\varphi \imath \lambda \varepsilon \tilde{)})$, tzn. lubią przechodzić jedne

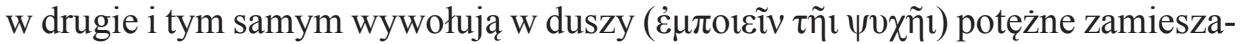

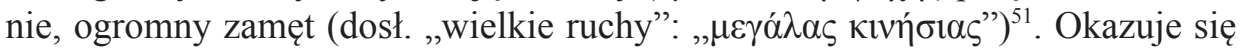
zatem, że duchowe centrum człowieka, czyli jego psyche, jest bardzo podatne na dobra zewnętrzne, do jakich niewątpliwie należą rzeczy materialne: majątek, dobra trwałe, pieniądze etc., określone gdzie indziej mianem przemijających (por.

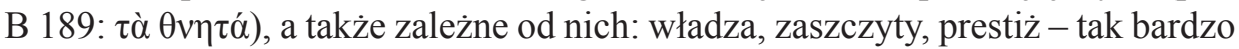
pożądane przez wielu, nawet gdy wymagają stosowania niedozwolonych metod czy wręcz łamania prawa, o czym przypomina Demokryt w dalszej części swej wypowiedzi. Filozof, jak widać, doskonale zna i rozumie ludzką naturę, zwłaszcza jednostek ambitnych, pozbawionych moralnych ograniczeń, gotowych - bez względu na cenę i ryzyko - ciągle dążyć do zmiany stanu posiadania. Często jednak takie działanie może kończyć się przykrą porażką, czego wyrazem stają się owe nagłe zwroty akcji, jakie niesie los: raz dla człowieka korzystny, innym razem zgubny. Nie sposób zatem nie zgodzić się z diagnozą Filozofa, że ofiarą takiego postępowania stają się dusze, nie zaznając ani spokoju ani szczęścia (oỡદ

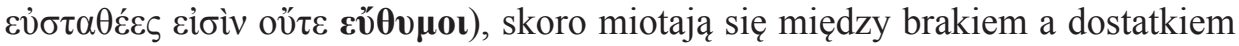

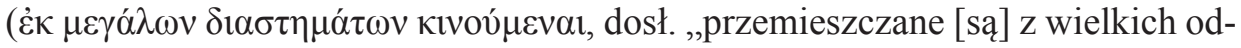
ległości”, tzn. między odległymi od siebie miejscami ${ }^{52}$, ubóstwem a bogactwem, nędzną egzystencją a pławieniem się w luksusach ${ }^{53}$. Te dwa skrajne bieguny

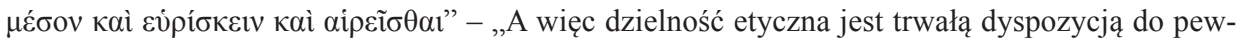
nego rodzaju postanowień, polegającą na zachowywaniu właściwej ze względu na nas średniej miary, którą określa rozum, i to w sposób, w jaki by ją określił człowiek rozsądny. Idzie tu o średnią miarę pomiędzy dwoma błędami, tj. między nadmiarem a niedostatkiem; a dalej: o średnią miarę o tyle, iż owe błędy bądź nie dochodzą do tego, co jest właściwe w doznawaniu namiętności i w postępowaniu, bądź poza tę granicę wykraczają, gdy natomiast dzielność etyczna znajduje i obiera właściwy środek" (tłum. D. Gromska, w: Arystoteles, Dzieła wszystkie..., 113).

${ }^{51}$ Laks (2017: 22) wyklucza, z czym w pełni się zgadzam, iż początek fragmentu B 191 mówi coś o atomowej budowie duszy w jej różnych stanach emocjonalnych, co wynika z jego oceny dwóch sfer w nauce Demokryta, o których dalej expressis verbis pisze tak: "[...] the two domains of ethics and physics are in some important respect independent of one another".

${ }^{52}$ Inaczej (niż w moim rozumieniu) wyjaśnia frazę „dusze poruszające się między przeciwnymi sobie stanami” Johnson (2020: 224), który sugeruje, iż Demokryt miałby tu na myśli osoby cierpiące na poważne zaburzenia psychiczne, w postaci silnych wahań nastroju, co we współczesnej medycynie określa się jako: „,choroba afektywna dwubiegunowa” i „psychoza maniakalno-depresyjna” (,bipolar disorder” and „manic-depressive disorder”). Johnson nie zauważa jednak, że Abderycie chodzi o źródło owych zaburzeń (np. ubóstwo - bogactwo), a nie ich 'niezwykłą' naturę; co więcej, stan, w którym dusza miota się między skrajnymi uczuciami, może dotknąć każdego z nas, a nie tylko osób dotkniętych daną jednostką chorobową.

${ }^{53}$ Taylor (1967: 13) interpretuje podobnie owo miotanie się dusz między skrajnościami,

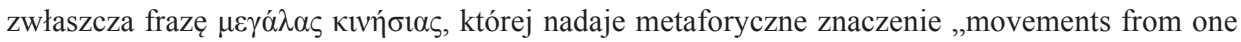
extreme to the other", interpretując cały passus w następujący sposób: ,that a soul which oscillates 
charakteryzują tych, dla których drogowskazem stają się emocje, np. wspomniany wyżej we fragmencie B 174 strach ( $\delta \varepsilon \delta \delta o 1 \kappa \varepsilon)$, uczucie wrogie racjonalnemu

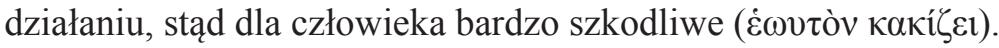

Dlatego jedyne rozwiązanie dostrzega Demokryt w koniecznym ograniczeniu wygórowanych ambicji i poprzestaniu na tym, co jest w naszym realnym

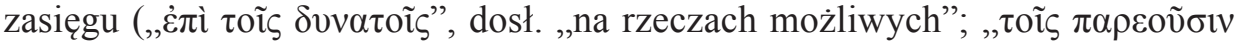
å $\kappa \varepsilon ́ \varepsilon \sigma \theta \alpha$ ”, dosł. „zadowalać się rzeczami, które są w pobliżu”). Recepta ta tylko pozornie wydaje się prosta, ponieważ, aby ją z powodzeniem zastosować, należy odrzucić uczucia i zastąpić je intelektem, obecnym w zastosowanej

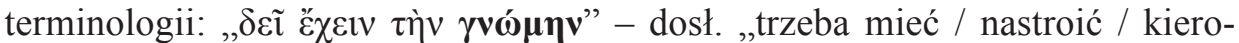

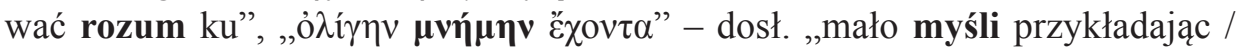

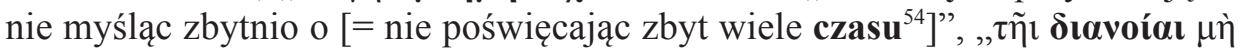
$\pi \rho 0 \sigma \varepsilon \delta \rho \varepsilon v ́ o v \tau \alpha "$ - dosł. „,nie przywiązując rozumu do [= nie zwracając uwagi

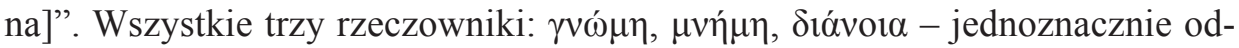
syłają zarówno do intelektualnej władzy, jaką sprawuje rozum (narzędzie poznania), jak i do efektu jego działania - myśli, wywołanej przez zewnętrzne rzeczy (dobra materialne), które zajmują naszą uwagę i którym człowiek nie powinien poświęcać cennego dlań czasu.

Jednak to tylko teoria, w praktyce bowiem do głosu dochodzą nasze uczucia - zachwyt i zazdrość, w takiej właśnie, jak się wydaje, kolejności, uobecnione

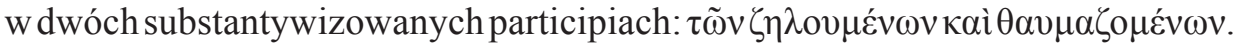
Chodzi zatem o „rzeczy, których się zazdrości [o które się współzawodniczy] i które się podziwia". Najpierw więc budzą w nas zdumienie, podziw, potem zaczynamy o nich intensywnie myśleć do tego stopnia, iż duszę nieuchronnie opanowuje zazdrość posiadania, która w końcu doprowadza ją do wielkiego

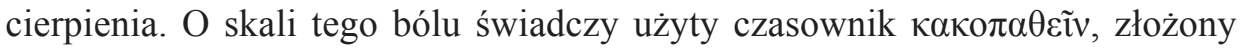

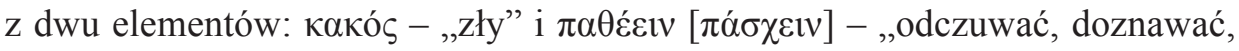
znosić, cierpieć". Odczuwane w duszy uczucie nie jest bynajmniej neutralne ani tym bardziej korzystne, wręcz przeciwnie, bardzo jej szkodzi. I dlatego należy zdaniem Filozofa - zachować się zupełnie inaczej: najpierw właściwie posłużyć się zmysłem wzroku, tzn. zacząć obserwować. Wystarczy uważnie przyjrzeć się

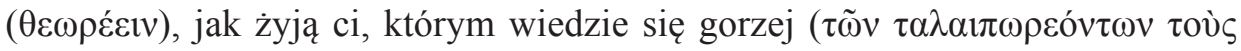

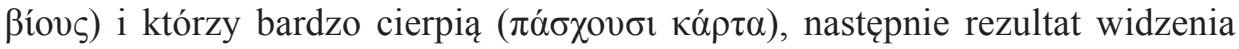

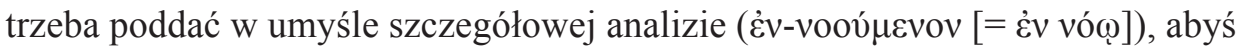
wreszcie Ty (człowieku), w niedalekiej przyszłości (cf. coniunctivus futurycz-

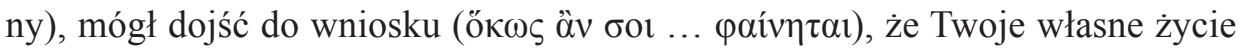

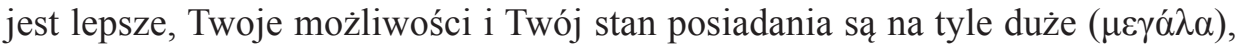

from one extreme of the pleasure-distress scale to the other cannot be stable, just as a pillar which shakes about, or weather which changes very rapidly, are not stable".

${ }^{54}$ O nowym znaczeniu, w jakim Demokryt używa we fragmencie B 191 rzeczownika mneme, mowa jest w monografii: Narecki 2020: 40-42. 


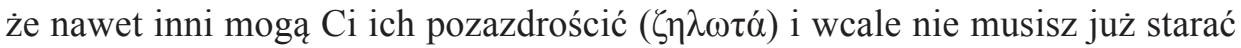

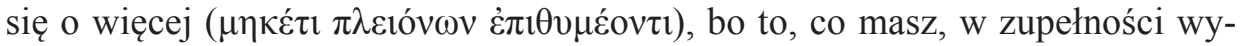

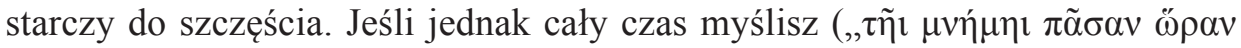
$\pi \rho 0 \sigma \varepsilon \delta \rho \varepsilon v ́ \omega v ”-$ dosł. „obok umieszczając / przykładając przez cały czas [cf.

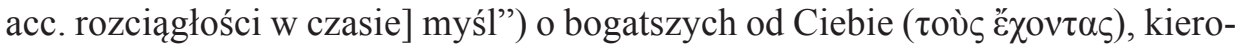

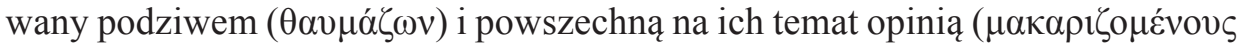

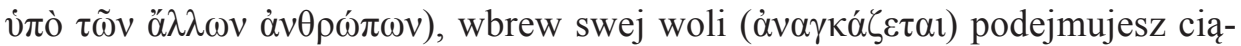

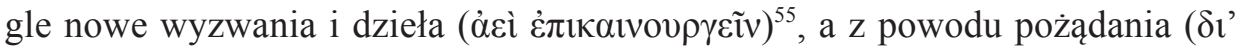

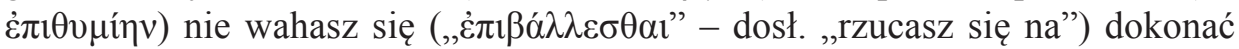

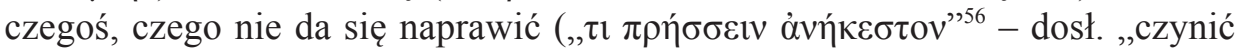
coś niedającego się uleczyć”). Konsekwencje takiego działania są jeszcze większe, ponieważ w kodeksie prawnym, jaki obowiązuje w polis, tego typu czyny

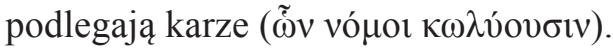

Skutki 'zaślepionego', nierozsądnego zachowania są więc dwojakie: po pierwsze, wyrządzona sobie samemu, nieuleczalna szkoda, po drugie zaś realna groźba penalizacji ze strony państwa, tj. surowych kar (więzienie, grzywna etc.). W obliczu takiego zagrożenia Ty (człowieku), jak po raz kolejny przekonuje Demokryt, zwracając się w drugiej osobie do swego odbiorcy, powinieneś odwrócić

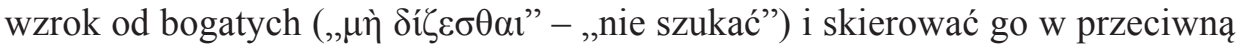

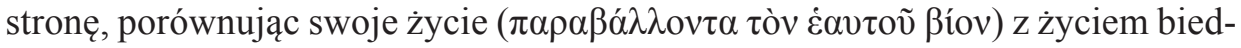

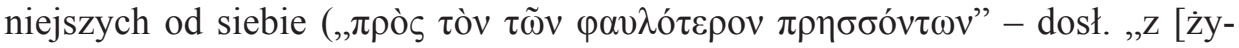
ciem] tych, którzy są w gorszym położeniu"). Filozof przywołuje tę samą, co wyżej, zasadę umiaru, której zalety człowiek dostrzeże tylko wtedy, gdy: (1) z pomocą intelektu zanalizuje ( $\dot{\varepsilon} v 0 v \mu \varepsilon v ́ \mu \varepsilon v o v$ ) obie egzystencje (swoją i biedne-

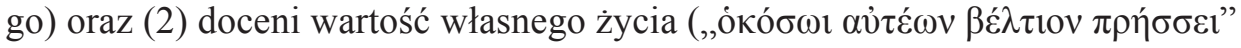
- „o ile lepiej od nich sobie radzi”), co więcej, (3) nabierze mocnego przekona-

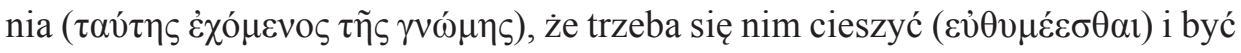
zdecydowanie szczęśliwszym ( $\varepsilon u ̉ \theta u \mu o ́ \tau \varepsilon \rho o v)$, niż miało to miejsce wcześniej,

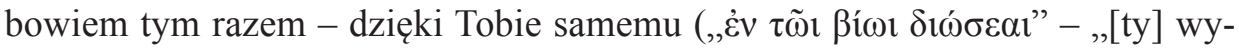
rzucisz z życia") - pozbędziesz się szkodliwych emocji: zazdrości, niezdrowej

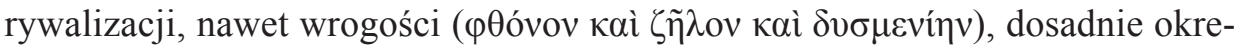

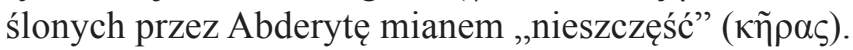

Jaka jest zatem recepta Filozofa, aby osiągnąć euthymia - „pogodę ducha”? W świetle fragmentu B 191 leży ona gdzieś pośrodku. Z jednej strony człowiek,

${ }^{55}$ Takie znaczenie sugeruje etymologia tego czasownika (nb. hapax legomenon w zachowanym greckim piśmiennictwie) złożonego z trzech elementów: przyimka غ̇đí (,przy, na, ku, do”),

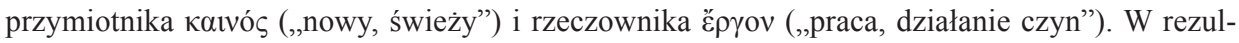

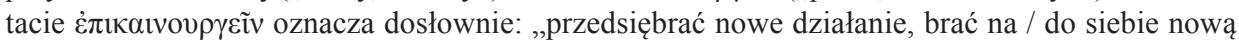
pracę" - cf. Lexicon of Presocratic Philosophy..., 152.

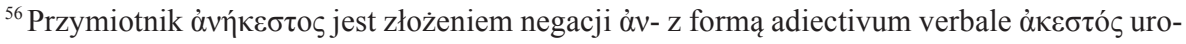
bioną od czasownika $\alpha \kappa \varepsilon ́ \varepsilon \sigma \theta \alpha 1$ („leczyć, goić, uzdrawiać, met. naprawić”) - vide Montanari 2015: 174. 
patrząc na bogatych, ulega złudnej i ryzykownej pokusie, zmysły bowiem przejmują na nim kontrolę, nadmierna zaś ambicja i żądza posiadania więcej prowadzą go niemal na skraj przepaści, podczas gdy jego dusza miota się między brakiem i nadmiarem. Dlatego tak ważną rolę ma do odegrania rozum. Jeśli uda mu się okiełznać uczucia, ustabilizować wewnętrzne drgania duszy i nad nią zapanować, następnie skierować wzrok tam, gdzie należy, włączyć poznanie $(\gamma v \omega ́ \mu \eta)$, wsparte przywołaniem - dzięki pamięci $(\mu v \eta \dot{\mu \eta})$ - minionych wydarzeń i zachowań, rozeznać dokładnie obecną sytuację za pomocą myśli ( $\delta$ ióvoła), by na końcu właściwie ocenić położenie (życie) swojego pana i władcy - to wówczas ten ostatni może śmiało powiedzieć, że odniósł sukces, ponieważ

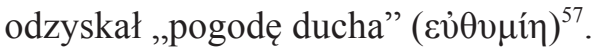

I jeszcze jedna konstatacja: Demokryt wcale nie odrzuca przyjemności, jak najbardziej je dopuszcza, ale tak jak całe życie, w którym winna panować rów-

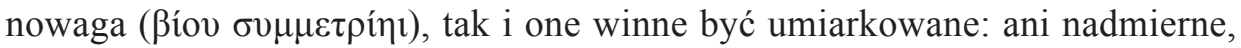

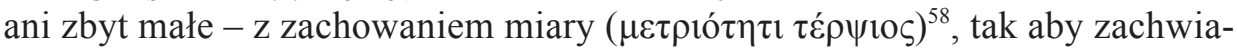
nie tej równowagi nie mogło zakłócić funkcjonowania rozumu i zniweczyć ciężkiej pracy, jaką wykonuje on, walcząc ze zrodzonymi w duszy emocjami. Abderyta odróżnia jednak dobra i przyjemności duchowe od doznań cielesnych, zdecydowanie preferując te pierwsze. Sam bowiem przestrzega człowie-

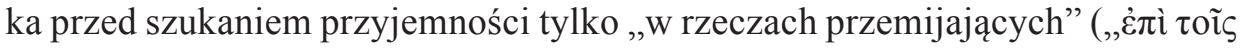
$\theta v \eta \tau o \tilde{\sigma} \iota "$ - w analizowanym wyżej fragmencie B 189), a we fragmencie B 37 konstatuje: ,ten, kto wybiera dobra duszy ( $\tau \grave{\alpha} \psi v \chi \eta \tilde{\varsigma} \varsigma \dot{\alpha} \gamma \alpha \theta \alpha$ ), wybiera bardziej boskie; ten zaś, kto [wybiera] dobra ciała ( Nie wolno więc marnować czasu na myślenie o bogactwie innych, bo - jak pokazuje Filozof - pragnienie zdobywania dóbr materialnych za wszelką cenę prowokuje złą stronę naszej natury i ujawnia jej ułomności (np. zawiść, zazdrość i wrogość).

\footnotetext{
${ }^{57}$ Niezwykle interesującą analizę euthymia jako pozytywnego stanu psychicznego, mającego zastosowanie w badaniach klinicznych nad leczeniem chorób psychicznych proponują G.A. Fava i P. Bech (Fava, Bech 2016: 1-5): ,there might be important applications of the concept of euthymia in the setting of medical disease. There has been recent interest in the relationship between psychological flexibility and chronic pain. Euthymia may affect how a person experiences the disease process. [...] As a construct of positive mental state, euthymia has to capture the items listed in table 1, i.e. living autonomously but with deep personal relationships, being cheerful and calm, feeling useful and active, and obtaining restorative sleep".

${ }^{58}$ Nill (1985: 77) wyodrębnia we fragmencie B 191 dwie kategorie umiaru, jakie niosą ze sobą przyjemności: po pierwsze, umiar w przyjemności polega na właściwej równowadze między różnymi przyjemnościami, które się dopuszcza; po drugie, umiar w przyjemności polega na przestrzeganiu granic danej przyjemności. Limity te są wyznaczone przez naturę; poza nimi jest nadmiar i ból: jeśli ktoś przekracza miarę, najprzyjemniejsze rzeczy stają się najbardziej nieprzyjemne.

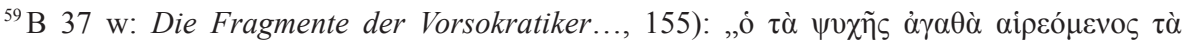

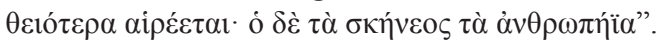


Dlatego trzeba cieszyć się każdym dobrem, jakie staje się naszym udziałem, o czym lapidarnie mówi Demokryt w kolejnym fragmencie:

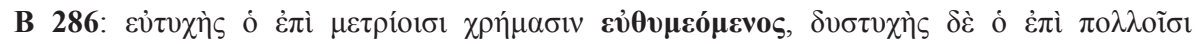
$\delta v \sigma \theta v \mu \varepsilon \hat{\mu \varepsilon v o \varsigma . ~}$

Szczęśliwy ten, kogo cieszy umiarkowane bogactwo, nieszczęśliwy zaś ten, kogo nawet wielkie napełnia smutkiem.

W tej krótkiej wypowiedzi, składającej się z dwu przeciwstawnych sobie, identycznie zbudowanych członów - zdań, kryje się recepta Filozofa na szczęśliwe życie. Aby jeszcze bardziej wyeksponować swoje przesłanie, stosuje on trzy

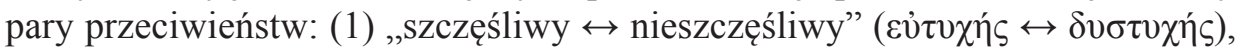

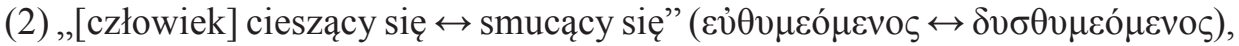
ten pierwszy z (3) „umiarkowanych dóbr $\leftrightarrow$ z licznych [dóbr]”, ten drugi (غ̇ंì

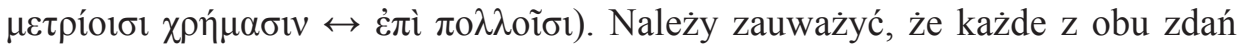
rozpoczyna się od elementu najważniejszego w tej sekwencji przyczyno-skutkowej: konkretny człowiek jest szczęśliwy (skutek), ponieważ umie się cieszyć (przyczyna wewnętrzna, duchowa) z bogactwa (przyczyna zewnętrzna, materialna), nawet jeśli jest ono niewielkie. I odwrotnie: człowiek jest nieszczęśliwy, cierpi (skutek), ponieważ jest smutny i nie potrafi się cieszyć (przyczyna duchowa) z bogactwa (przyczyna materialna), choć jest ogromne ${ }^{60}$. Wydaje się, że obecność w trzeciej parze przymiotnika $\pi$ o $\lambda \lambda$ oĩ $\sigma$, określającego wielkość bogactwa, pozwala przypuszczać, że radość może sprawić człowiekowi nawet mały, skromny majątek, postrzegany nierzadko jako stan ubóstwa, który mimo

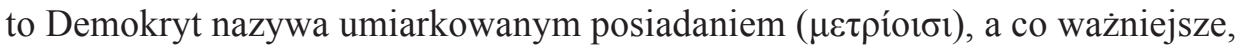
uznaje je za warunek ,pogody ducha”. Aby więc człowiek poczuł się szczęśli-

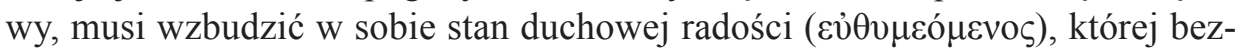
pośrednią przyczyną jest zachowanie umiaru w stosunku do dóbr materialnych,

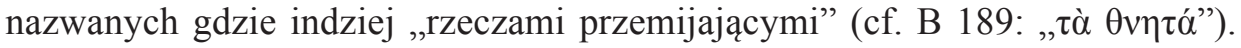
Jeśli jednak zapomni się o tej zasadzie, gromadząc coraz więcej bogactwa, które staje się celem samym w sobie, wówczas budzą się złe uczucia: zazdrość, wrogość, niezdrowa rywalizacja, dążenie za wszelką cenę do zwycięstwa (w byciu najbogatszym, najbardziej wpływowym) - i tym sposobem człowiek, ulegając smutkowi ( $\delta v \sigma \theta v \mu \varepsilon \delta$ $\mu \varepsilon v o \varsigma)$, staje się nieszczęśliwy.

O właściwej dystrybucji majątku muszą jednak pamiętać rodzice, kiedy przychodzi pora, aby bezpiecznie przekazać go swoim dzieciom:

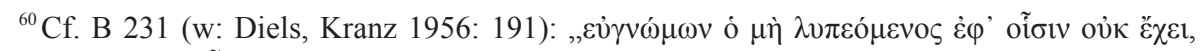

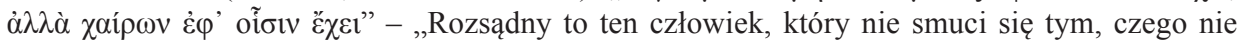

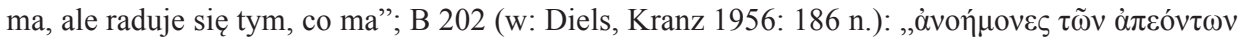

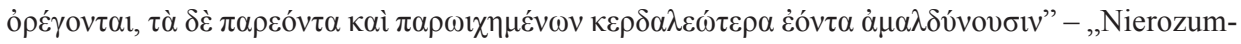
ni uganiają się za tym, czego nie ma, zaniedbują zaś to, co mają, nawet jeśli jest to cenniejsze aniżeli to, co [im] umyka". 


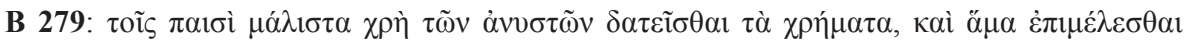

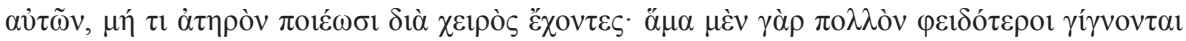

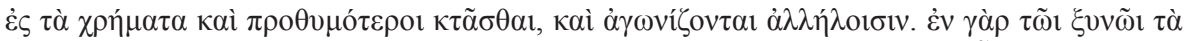

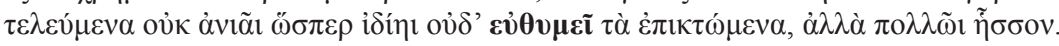

Pomiędzy [swoich] synów należy w najlepszy możliwy sposób rozdzielać majątek, a równocześnie troszczyć się, aby nie popełnili żadnego błędu, kiedy już dostaną go w swoje ręce. W tym samym bowiem czasie stają się o wiele bardziej oszczędni - co się tyczy majątku i chętniej starają się o więcej, nadto ze sobą współzawodniczą. Wszak wydawanie pieniędzy we wspólnym majątku nie smuci tak [bardzo] jak wydawanie ich samodzielnie, nie cieszą też [wspólne] przychody, ale znacznie mniej.

Wprawdzie Demokryt kilka razy w zachowanych wypowiedziach (zob. wyżej: B 189, B 191, B 286) postuluje umiar w dążeniu do rzeczy doczesnych, zalecając, aby zadowalać się tym, co mamy, skoro nabywanie dóbr materialnych za wszelką cenę zakłóca harmonię między nadmiarem a niedostatkiem i budzi zgubne dla duszy emocje, jednak w analizowanym fragmencie przedmiotem troski Filozofa staje się właśnie majątek, przynajmniej na pierwszy rzut oka, bo tak naprawdę chodzi o zachowanie rozwagi i właściwej proporcji przy przekazywaniu spadku swoim dzieciom. Ojcowie mają więc najlepiej, jak potrafią, wedle ojcowskiego rozeznania, nie tylko podzielić zgromadzony majątek ( $\mu \alpha \dot{\lambda} \imath \_\tau \alpha \ldots$

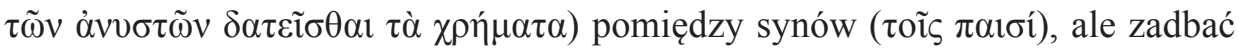

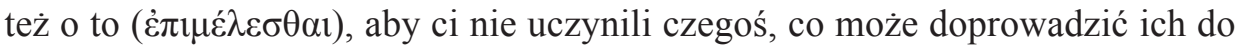

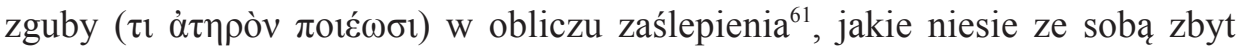
wielkie bogactwo. Jest to więc pedagogia pełnej odpowiedzialności za czyny swoich dzieci, nawet jeśli są już dorosłe. Tak dojrzała postawa wynika z doświadczenia dorosłych, którzy zdają sobie sprawę ze zmiany sposobu myślenia i działania młodych, kiedy ze zwykłych 'konsumentów' dobrodziejstw, jakie na co dzień spotykają ich w domu rodzinnym, stają się pełnoprawnymi właścicielami rodzinnego spadku bądź jego części. To dość radykalna zmiana, w wyni-

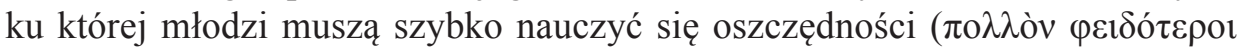

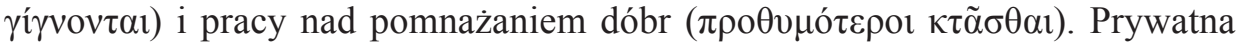
własność przewartościuje zatem postępowanie młodego człowieka, który nie tylko stara się mieć więcej, lecz także chętnie podejmuje rywalizację z innymi,

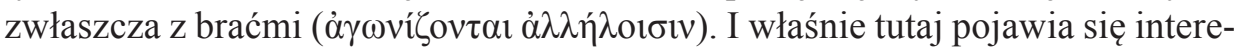
sujący nas czasownik „,cieszyć się” (spokrewniony z rzeczownikiem euthymia) w opozycji do „smucić się” w kontekście wydawania pieniędzy. Nie może dziwić beztroska młodego człowieka, który wcale się nie smuci, a nawet więcej,

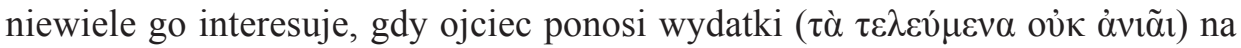
utrzymanie potomstwa i domu, gdzie zamieszkuje jego rodzina. Nie cieszy też

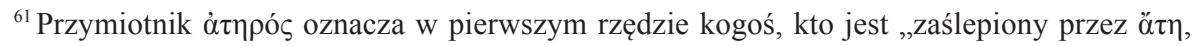
pchany do zguby”, a substantywizowany wskazuje na „zgubę, nieszczęście” (vide Montanari 2015: 330), albo coś, co „niesie katastrofę” („bringing disaster” - vide Beekes 2010: 163).
} 
młodzieńca (ov̉ $\delta^{\prime}$ củ $\left.\theta v \mu \varepsilon \tilde{\imath}\right)$, bo nie jest to przedmiotem jego zainteresowania, gdy ojciec troszczy się o przychody ( $\tau \grave{\alpha} \dot{\varepsilon} \pi \imath \kappa \tau \omega ́ \mu \varepsilon v \alpha$ ), o ciągłe zdobywanie środków, które służą potem wszystkim domownikom. Stopień zadowolenia jest wówczas zdecydowanie mniejszy ( $\pi \mathrm{o} \lambda \lambda \tilde{\omega} \mathrm{i} \tilde{\eta} \sigma \sigma o v)$ niż w sytuacji, gdy syn przejmuje pełną odpowiedzialność za powierzony mu majątek, zmieniając swój status z biernego 'zjadacza' dóbr na pełnoprawnego ich właściciela. To ostatnie stwierdzenie, choć Demokryt explicite o tym nie mówi, wynika wprost z logiki tego zdania: o wiele bardziej cieszą pieniądze zdobyte osobiście, prywatnie, na własny rachunek, co wyraźnie sugeruje przysłówek iónin. Podobnie, czyli w wysokim stopniu, obdarowany syn martwi się, kiedy ma wydawać z trudem zdobyte pieniądze, ale tym razem już z osobistego 'konta'. W rozumowaniu Abderyty najistotniejsze są dwie pary przeciwstawnych pojęć: 1. Czasowniki: „smucić - cieszyć”, ảviã - $\varepsilon \dot{ } \theta 0 \mu \varepsilon i ̃$; oraz 2. Dwa przysłówki (pierwszy jako wyrażenie przyimkowe):

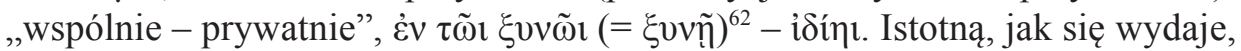
rolę w wyrażaniu uczuć pełni tu grecka idea współzawodnictwa ${ }^{63}$, o czym przypomina czasownik à $\gamma \omega v i \zeta \zeta o v \tau \alpha$. Smuci więc wydawanie z własnych zasobów, bo odbierane jest jako porażka, cieszy zaś sukces $w$ ich zdobywaniu. W świetle przeprowadzonej analizy fragmentu B 279 można wnioskować, iż czasownik

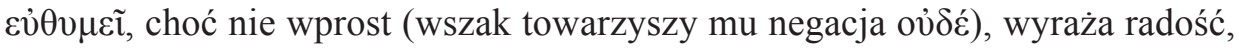
jaką młody człowiek czerpie ze zdobytych, często we współzawodnictwie z innymi, dóbr materialnych, których, jak poucza Demokryt, mądra dystrybucja (przez głowę rodu) staje się narzędziem odpowiedzialnego wychowania. Należy też pamiętać, że staraniom młodych o utrzymanie i pomnożenie majątku zawsze będą towarzyszyć przeciwstawne uczucia: smutek i radość, które rodzą się w zdrowej rywalizacji, bo albo się wygrywa, albo ponosi porażkę.

Analiza wszystkich 9 fragmentów, w których pojawia się zarówno rzeczow-

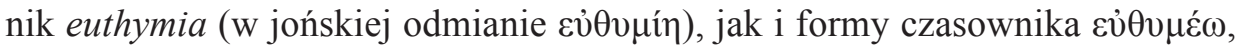
a także spokrewniony z nimi przymiotnik $\varepsilon u ̈ \theta v \mu o \varsigma$, wskazuje, że pojęcie to -

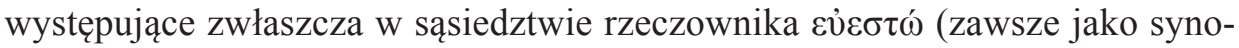
nimu), jak chociażby w tytule jednego z traktatów etycznych Demokryta: „Пєрì

${ }^{62}$ Vide Montanari 2015: 1419, podobnie Liddell, Scott 1996: 1192.

${ }^{63}$ Szerzej na ten temat pisze Słapek (2010: 147-150) pod hasłem „Agonistyka”. Istotę tego fenomenu dostrzega on w postawie życiowej Greków, zawierającej się w deklaracji aien aristeuein - ,zawsze być najlepszym, pierwszym”, co oznaczało w praktyce, iż współzawodnictwo i rywalizacja nadawały ton całej greckiej kulturze, ogarniając wiele różnych sfer życia i twórczości: duchowej, intelektualnej i artystycznej; co więcej, walkę toczono też o spadek i majątek. Warto przypomnieć tu pogląd Arystotelesa, który w Etyce Nikomachejskiej tłumaczy, iż motywem skłaniającym Hellenów do udziału w rywalizacji (gry, zabawy, zawody, konkursy) było ich głębokie pragnienie współżycia społecznego. Szerzej na ten temat pisze Skultety (2009: 44-68). 


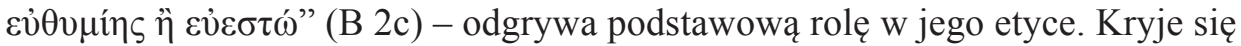
w nim szerokie spektrum znaczeniowe. Bez przesady można nawet stwierdzić, iż euthymia identyfikuje cały proces prowadzący do celu $(t e l o s)^{64}$, w tym warunki i sposób osiągnięcia tego, co dla człowieka najważniejsze, tj. stanu szczęścia (eudaimonia), do którego zdąża on przez całe swoje życie ${ }^{65}$. Już sam Abderyta miał chyba pewien problem z zakresem semantycznym tego pojęcia, skoro po-

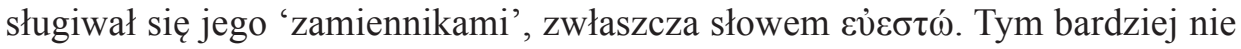
dziwi trudność, z jaką zmagają się badacze, usiłując znaleźć jeden, adekwatny odpowiednik we własnym języku. W proponowanych przekładach najczęściej nadaję rzeczownikowi euthymia(-e) znaczenie ,pogoda ducha”. Uważam tę propozycję za najbardziej zbliżoną do wiodącego sensu, jaki w tym pojęciu się kryje. Nie wyczerpuje to jednak całego jego zakresu semantycznego ${ }^{66}$.

Czym zatem, w świetle zachowanych fragmentów, jest euthymia? Dzięki świadectwu Hezychiusza (B 140) oraz Diogenesa (D.L. 9.45), u którego pojawia

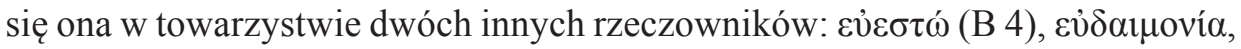
wiadomo, że jej zakres semantyczny jest znacznie szerszy, wskazuje bowiem na dobrą kondycję duchową człowieka, konieczną do osiągnięcia stanu szczęścia: euthymie gwarantuje w ten sposób wewnętrzny porządek, ład i spokój (jak ma to miejsce w dobrze urządzonym domu), przynosząc upragnione „dobre samopoczucie, błogostan” (euesto) i „szczęście (eudaimonia) ${ }^{67}$. Aby jednak stało się to możliwe, człowiek musi, posłuszny wewnętrznemu imperatywowi (co postuluje Demokryt, używając wyrażeń $\delta \varepsilon \tilde{~ l u b ~} \chi \rho \eta ́)$, wypełnić kilka warunków:

1. Nie może podejmować się zbyt wielu zadań czy to w życiu prywatnym, czy publicznym, musi bowiem uwzględnić możliwości własnej natury (ciała i ducha), dodatkowo działając zgodnie z zasadą umiaru, wyrażoną w zaleceniu, że „właściwa miara jest bezpieczniejsza od nadmiaru” (B 3), co oznacza, że duchowe zadowolenie rodzi się z umiarkowanej przyjemności i harmonijnego życia (B 191).

\footnotetext{
${ }^{64}$ Kahn (1998: 36-37) słusznie zauważa, że choć prawdą jest, że Demokryt uważa spokój ducha (euthymiē) za taki stan duszy, jakiego pragnąłby każdy człowiek, to jednak ujmowanie tego stanowiska „in terms of the post-Aristotelian concept of the telos is more than anachronistic”. $\mathrm{Z}$ drugiej strony kategoryczne stwierdzenie Autora, że „we fragmentach Stagiryty nie ma niczego, co sugerowałoby, że wszystkie ludzkie działania zmierzają lub powinny zmierzać do jednego celu", wydaje się - w świetle naszych analiz - zbyt radykalne.

${ }^{65}$ Nie sposób zgodzić się ze stanowiskiem G. Striker (1990: 98), która w wypowiedziach Demokryta nie dostrzega argumentacji pokazującej, iż euthymia jest dobrem człowieka, celem życia czy też jest tożsama ze szczęściem.

${ }^{66}$ Dlatego w najnowszym opracowaniu etycznych maksym Demokryta jego autor, Johnson

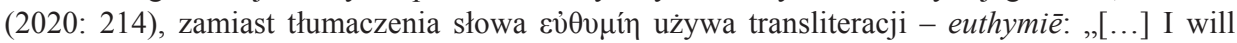
generally use a transliteration of the term euthumie instead of a translation".

${ }^{67}$ Jak zauważa P. Curd (w: Preus 2001: 155), wszystkie etyczne fragmenty Demokryta „seem to reach this conclusion, that the best and happiest life for a human being is a well-ordered one in which pleasures are moderate, and in which one seeks modest enjoyment".
} 
2. Zna prawo (tak zwyczajowe, jak i stanowione) i zgodnie z jego wymogami zawsze postępuje sprawiedliwie, dzięki czemu zyskuje ,pogodne usposobienie" ( $\varepsilon \ddot{v} \theta v \mu \circ)$ ), pozbywa się trosk oraz nabiera sił i życiowej energii (B 174); co więcej, na sprawiedliwym człowieku spoczywa również obowiązek eliminowania szkodników zagrażających tak jednostce, jak i każdemu porządkowi państwa: takie zachowanie przynosi wszak większy „spokój ducha” (euthymie) i inne wspomagające go cnoty oraz dobra doczesne (B 258).

3. Świadomie ogranicza doraźne przyjemności (ídovaí), jakich dostarczają rzeczy przemijające ( $\tau \grave{\alpha} \theta v \eta \tau \alpha ́)$, dopiero wtedy bowiem może spędzać życie

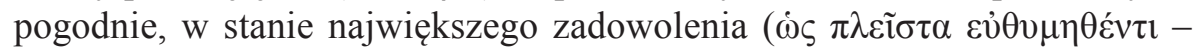
B 189).

4. Umie cieszyć się każdym dobrem materialnym, nawet jeśli jest ono niewielkie, wzbudzając w sobie stan duchowej radości ( $\varepsilon \dot{\theta} \theta v \mu \varepsilon o ́ \mu \varepsilon v o \varsigma ~-~ B ~ 286)$; bezpośrednią jej przyczyną jest, tak jak w przypadku uczuć, zachowanie umiaru w korzystaniu z dóbr doczesnych, które przynoszą większą radość, ale pod warunkiem, że zdobywa się je osobiście, zwłaszcza w zdrowej rywalizacji z innymi (B 279).

5. Ceni sobie - dzięki zaangażowaniu rozumu i opanowaniu negatywnych uczuć - wartość własnego życia, nabierając mocnego przekonania, że trzeba się nim cieszyć ( $\varepsilon \dot{\theta} \theta 0 \mu \varepsilon ́ \varepsilon \sigma \theta \alpha$ ) i być zdecydowanie szczęśliwszym

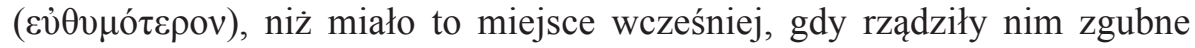
emocje (B 191).

Jak więc - zdaniem Demokryta - osiągnąć „pogodę ducha”? W świetle wszystkich jego wypowiedzi najważniejsza jest właściwa miara w korzystaniu $z$ dóbr i równowaga wewnętrzna oraz umożliwiające je: rozum i wiedza ${ }^{68}$. Aby

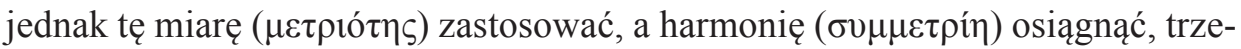
ba użyć władzy intelektu. Jeśli uda mu się okiełznać uczucia, ustabilizować wewnętrzne drgania duszy i nad nią zapanować, włączyć poznanie ( $\gamma v \omega ́ \mu \eta)$, wsparte pamięcią ( $\mu v \eta ́ \mu \eta)$ o doświadczonych wydarzeniach i zachowaniach, rozeznać

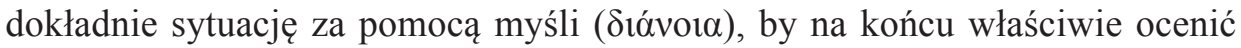
swoje położenie ( $\beta$ ín - „życie”) - to wówczas człowiek może śmiało powie-

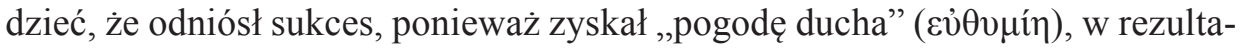
cie zaś wewnętrzny błogostan: radość i szczęście.

\footnotetext{
${ }^{68}$ Podobne stanowisko zajmuje S.H. Svavarsson (2015: 197), który właśnie mądrość („the wisdom”) czyni odpowiedzialną za osiągnięcie przez człowieka „tranquillity or some kind of mental contentment”, także ,peace of mind”, a w rezultacie szczęścia - „happiness”. Jeszcze dobitniej wyraża to Annas (2016: 180), pisząc, że dla Demokryta „only the reasoned and rationally ordered life has a hope of being happy".
} 


\section{BIBLIOGRAFIA}

Źródła, przekłady, komentarze

Arystoteles, Dzieła wszystkie, t. V: Etyka Nikomachejska. Etyka wielka. Etyka eudemejska. $O$ cnotach $i$ wadach, przekł., wstępy i koment. D. Gromska, L. Regner, W. Wróblewski, Warszawa 2000.

R. Beekes, Etymological Dictionary of Greek, Leiden-Boston 2010.

Die Fragmente der Vorsokratiker, griechisch und deutsch von H. Diels, Aufl. hrsg. von W. Kranz, Berlin $1956^{8}$.

F. Enriques, M. Mazziotti, Le dottrine di Democrito d'Abdera. Testi e commenti, cura e saggio introduttivo di M.A. Duca, prefazione di G. Sgro', Napoli 2016.

Diogenes Laertios, Żywoty i poglady słynnych filozofów, przeł. I. Krońska [i in.], Warszawa 1982 [= Krońska 1982].

B. Kupis, Fragmenty Presokratyków. Demokryt (II), „Meander” 59/3-4 (2004), 181-202.

A. Laks, Early Greek Philosophy, vol. VII: Later Ionian and Athenian Thinkers. Part 2, eds. and transl. by A. Laks, G. W. Most, Loeb Classical Library 530, Cambridge 2016.

Lexicon of Presocratic Philosophy, Academy of Athens, Research Center for Greek Philosophy, Athens 1988.

H.G. Liddell, R. Scott, Greek-English Lexicon, revised and augmented by H.S. Jones with the assistance of Roderick McKenzie. Supplement ed. by P.G.W. Glare, Oxford 1996.

Diogenis Laertii, Vitae philosophorum, recognovit brevique adnotatione critica instruxit H.S. Long, vol. II, Oxonii 1964 [= Long 1964].

F. Montanari, The Brill Dictionary of Ancient Greek, editors of the English Edition Madeleine Goh \& Chad Schroeder under the auspices of the Center for Hellenic Studies, Harvard University, advisory Editors Gregory Nagy, Leonard Muellner, Leiden-Boston 2015.

Taylor, The Atomists: Leucippus and Democritus. Fragments, a Text and Translation with a Commentary by C.C.W. Taylor, Toronto 1999.

R. Waterfield, The First Philosophers. The Presocratics and Sophists, transl. with Commentary by R. Waterfield, Oxford 2000.

\section{Opracowania}

Annas 2016: J. Annas, Democritus and Eudaimonism, w: Presocratic Philosophy: Essays in Honor of Alexander Mourelatos, eds. by V. Caston, D.W. Graham, London-New York, 169-80.

Edmunds 1972: L. Edmunds, Necessity, Chance, and Freedom in the Early Atomists, „Phoenix” 26 (1972), 342-357.

Fairbanks 1897: A. Fairbanks, On Plutarch's Quotations from the Early Greek Philosophers, „Transactions and Proceedings of the American Philological Association” 28 (1897), 75-87.

Farrar 1989: C. Farrar, The Origins of Democratic Thinking: The Invention of Politics in Classical Athens, Cambridge 1989.

Fava, Bech 2016: G.A. Fava, P. Bech, The Concept of Euthymia, „Psychotherapy and Psychosomatics" 85/1 (2016), 1-5.

Fowler 1890: H. N. Fowler, Plutarch $\pi \varepsilon \rho \imath \varepsilon v \theta v \mu l \alpha \varsigma$, ,Harvard Studies in Classical Philology” 1 (1890), 139-152.

Gajda-Krynicka 2001: J. Gajda-Krynicka, Demokryt, w: Powszechna Encyklopedia Filozofii, t. II, Lublin 2001, 476-478.

Guthrie 1965: W.K.C. Guthrie, A History of Greek Philosophy, vol. II: The Presocratic Tradition from Parmenides to Democritus, Cambridge 1965.

Hershbell 1982: J.P. Hershbell, Plutarch and Democritus, „Quaderni Urbinati di Cultura Classica” 10 (1982), 81-111.

Johnson 2014: M.R. Johnson, Changing our minds: Democritus on what is up to us, w: Studies on Causality and Responsibility in Ancient Philosophy, California 2014, 1-17. 
Johnson 2020: M.R. Johnson, The Ethical Maxims of Democritus of Abdera, w: Early Greek Ethics, ed. by D.C. Wolfsdorf, Oxford 2020, 211-242.

Kahn 1985: Ch. H. Kahn, Democritus and the Origins of Moral Psychology, „The American Journal of Philology" 106 (1985), 1-31.

Kahn 1998: Ch. H. Kahn, Pre-Platonic Ethics, w: Companions to Ancient Thought: 4. Ethics, ed. by S. Everson, Cambridge 1998.

Laks 2017: A. Laks, What is Pre-Socratic Ethics?, w: The Cambridge Companion to Ancient Ethics, ed. by Ch. Bobonich, Cambridge 2017, 11-29.

Long 1999: The Cambridge Companion to Early Greek Philosophy, ed. by A.A. Long, Cambridge 1999.

McGibbon 1960: D. McGibbon, Pleasure as the „Criterion” in Democritus, „Phronesis” 5 (1960), $75-77$.

Michaelides, Kardasi, Milios 2011: P. Michaelides, O. Kardasi, J. Milios, Democritus's Economic Ideas in the Context of Classical Political Economy, „European Journal of the History of Economic Thought" 18/1 (2011), 1-18.

Narecki 2020: K. Narecki, Mneme w epoce przedsokratyków, Lublin 2020.

Nill 1985: M. Nill, Morality and Self-Interest in Protagoras, Antiphon, and Democritus, Leiden 1985.

Preus 2001: Essays in Ancient Greek Philosophy VI. Before Plato, ed. by A. Preus, Albany 2001.

Procopé 1989: J.F. Procopé, Democritus on Politics and the Care of the Soul, „The Classical Quarterly" 39/2 (1989), 307-331.

Reale 1993: G. Reale, Historia filozofii starożytnej, t. I: Od początków do Sokratesa, przeł. E.I. Zieliński, Lublin 1993.

Rowe, Schofield 2008: The Cambridge History of Greek and Roman Political Thought, ed. by Ch. Rowe and M. Schofield in association with S. Harrison and M. Lane, Cambridge 2008.

Skultety 2009: S.C. Skultety, Competition in the Best of Cities: Agonism and Aristotle's „Politics”, „Political Theory” 37/1 (2009), 44-68.

Słapek 2010: R. Słapek, Sport i widowiska w świecie antycznym. Kompendium, Kraków-Warszawa 2010.

Striker 1990: G. Striker, Ataraxia: Happiness as Tranquillity, „The Monist” 73/1 (1990), 97-110.

Svavarsson 2015: S.H. Svavarsson, The Pyrrhonian Idea of a Good Life, w: The Quest for the Good Life. Ancient Philosophers on Happiness, eds. Ø. Rabbås, E. K. Emilsson, H. Fossheim, M. Tuominen, Oxford 2015.

Taylor 1967: C.C.W. Taylor, Pleasure, Knowledge and Sensation in Democritus, „Phronesis” 12/1 (1967), 6-27.

Vamvacas 2009: C.J. Vamvacas, The Founders of Western Thought - The Presocratics. A Diachronic Parallelism between Presocratic Thought and Philosophy and the Natural Sciences, transl. by R. Crist, Dordrecht 2009.

Vlastos 1945: G. Vlastos, Ethics and Physics in Democritus (Part One), „Philosophical Review” 54 (1945), 578-592.

Vlastos 1946: G. Vlastos, Ethics and Physics in Democritus (Part Two), „Philosophical Review” 55 (1946), 53-64.

Warren 2002: J. Warren, Epicurus and Democritean Ethics: An Archaeology of Ataraxia, Cambridge 2002.

Warren, Sheffield 2014 (eds.): J. Warren, F. Sheffield, The Routledge Companion to Ancient Philosophy, ed. by J. Warren and F. Sheffield, New York 2014.

Wolfsdorf 2013: D. Wolfsdorf, Pleasure in Ancient Greek Philosophy, Cambridge 2013. 


\section{EUTHYMIA IN THE FRAGMENTS OF DEMOCRITUS OF ABDERA}

\section{Summary}

The analysis of 9 passages in which the noun $\varepsilon \dot{v} \theta v \mu$ in, the verb $\varepsilon \dot{v} \theta v \mu \varepsilon \dot{\varepsilon} \omega$ and the related adjective

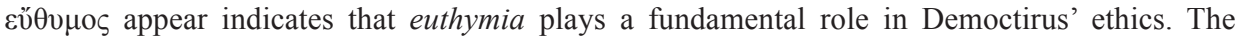
concept covers a wide range of meanings, including the entire process that leads to happiness (eudaimonia). The philosopher also substitutes the word euthymie with other words, including the noun $\varepsilon \dot{\varepsilon \sigma \tau \omega ́}$. In my translations euthymie is given the meaning of „cheerfulness.” The analyses show that euthymie primarily means a good spiritual condition of a person. It provides internal, spiritual order and peace, resulting in "happiness" (eudaimonia). However, to make this possible, people - being obedient to inner necessity (which Democritus postulates using the expressions $\delta \varepsilon \tilde{i}$ or $\chi \rho \eta ́)-$ must fulfill several conditions:

1. They cannot perform too many tasks in private and public life, for they must take into account the abilities of their body and spirit and act in accordance with the principle of moderation (expressed in the recommendation: ,the right measure is safer than excess" - B 3), which teaches them that spiritual satisfaction comes from temperance in one's pleasures and from harmonious life (B 191). 2. They know the law and always act justly in accordance with its requirements. Thanks to such conduct they get rid of their worries, gain strength and life energy (B 174), and eliminate beings that threaten them and the state (B 258).

3. They consciously limit the immediate pleasures provided by transient things (B 189).

4. They know how to enjoy any material good, even if it is small (B 286). They acquire wealth in moderation and in healthy competition with others (B 279).

5. They appreciate the value of their own life and are aware of the disastrous impact of emotions on their life. They also know that it is necessary to enjoy life and be more cheerful, even if they own little (B 191).

Therefore, the most important things in getting into the state of ,cheerfulness" are the right use of goods, internal balance, as well as reason and knowledge that lead to them. If a person is able to tame one's feelings, stabilise the soul, enable cognition ( $\gamma v \omega \dot{\mu} \mu \eta)$ supported by memory ( $\mu v \eta \dot{\mu \eta})$ of the past, and discern the situation accurately using thoughts ( $\delta i^{\prime} v o 1 \alpha$ ) in order to properly evaluate one's life, then this person achieves „cheerfulness”, and consequently, the desired goal, i.e. happiness. 